\title{
Firm-Level Heterogeneity of Clawback Provisions
}

\author{
Michael H.R. Erkens ${ }^{\mathrm{a}}$ \\ Ying Gan ${ }^{\mathrm{b}, *}$ \\ B. Burcin Yurtogluc
}

This version: January 14, 2014

\begin{abstract}
We investigate the degree to which implementing a clawback policy, a special part of the executive's compensation contract, is an adequate governance mechanism to deter executives from misbehavior and to recover excess-pay. By focusing on the firm-level heterogeneity in the structure of clawbacks, we recognize that firms have considerable discretion in how they design their policies. We find that firms make heavily use of their discretion in adopting more or less deterrent policies and that most firms have weak clawback provisions. We analyze voluntary adopted clawbacks of all Russell 3,000 non-financial firms over 2007-2012. We conduct an extensive linguistic and a factor analysis to construct a deterrent index for 3,578 clawback observations. This index reflects the degree to which the contractual form of each clawback contains the core elements of a deterrent clawback policy. Our results, which also take into account the self-selection problem of voluntarily adopting a clawback, show that executive power, the executives' pay level, and weak corporate governance are associated with a low deterrent level. We also find that the deterrent level increases in directors' experience, corporate profitability and management ownership.
\end{abstract}

Keywords: clawback provisions, excess pay, corporate governance, linguistic analysis JEL codes: G18, G30, G34, G39, K22, K29

${ }^{a}$ HEC Paris, Department of Accounting, 78351 Jouy en Josas, France; erkens@hec.fr

b WHU Otto-Beisheim-School of Management, 56179 Vallendar, Germany; gan@whu.edu

${ }^{\text {c} W H U ~ O t t o-B e i s h e i m-S c h o o l ~ o f ~ M a n a g e m e n t, ~} 56179$ Vallendar, Germany; yurtoglu@whu.edu

${ }^{*}$ Corresponding author

We are grateful for comments and suggestions to Yakov Amihud, Lucio Carta, Hans B. Christensen, Markus Justen, Christian Leuz, Wolf Michael Nietzer, Marc-Roger Schlieper, Florin Vasvari, David Veenman, and seminar participants at the WHU - Otto Beisheim School of Management (2012), and the GEABA annual meeting 2013. We thank Konstantin Danilov, Amey Deshpande and Yitong Sun for their valuable research assistance. 


\title{
Firm-Level Heterogeneity of Clawback Provisions
}

\begin{abstract}
We investigate the degree to which implementing a clawback policy, a special part of the executive's compensation contract, is an adequate governance mechanism to deter executives from misbehavior and to recover excess-pay. By focusing on the firm-level heterogeneity in the structure of clawbacks, we recognize that firms have considerable discretion in how they design their policies. We find that firms make heavily use of their discretion in adopting more or less deterrent policies and that most firms have weak clawback provisions. We analyze voluntary adopted clawbacks of all Russell 3,000 non-financial firms over 2007-2012. We conduct an extensive linguistic and a factor analysis to construct a deterrent index for 3,578 clawback observations. This index reflects the degree to which the contractual form of each clawback contains the core elements of a deterrent clawback policy. Our results, which also take into account the self-selection problem of voluntarily adopting a clawback, show that executive power, the executives' pay level, and weak corporate governance are associated with a low deterrent level. We also find that the deterrent level increases in directors' experience, corporate profitability and management ownership.
\end{abstract}

Keywords: clawback provisions, excess pay, corporate governance, linguistic analysis JEL codes: G18, G30, G34, G39, K22, K29 


\section{Introduction}

Companies voluntarily started to install clawback policies in mid-2000 after the Enron Corp. and WorldCom Inc. scandals. On the regulatory side, the first compensation recoupment provision (clawback) was introduced in Section 304 of the Sarbanes-Oxley Act in 2002 (hereafter, SOX clawback). SOX 304 entitles the Securities and Exchange Commission (SEC) to enforce the recoupment of erroneously awarded compensation (excess-pay) paid to chief executive officers (CEOs) and chief financial officers (CFOs) of public firms in the event of "an accounting restatement due to the material noncompliance of the issuer [firm], as a result of misconduct”. ${ }^{1}$ The SOX clawback has been supposed to deter executives from misstating their firms' financial positions, but it has been proved to be a dormant enforcement tool. Although there have been thousands of restatements since 2002, the SEC brought its first case not until 2007. Since then it has exercised its clawback powers in only 31 cases (Salehi and Marino 2008, Morgenson 2013). To promote the enforcement of clawbacks, the Dodd-Frank Wall Street Reform and Consumer Protection Act (DFA) introduces a section (Section 954) on the recoupment of excess pay to facilitate the enforcement of clawbacks at the firm-level in 2010 (hereafter, DFA clawback). The purpose of clawbacks under both regulatory regimes has, however, not changed: Clawbacks aim to mitigate agency problems arising due to the separation of ownership and control.

From the principal agency theory's point of view, clawback provisions, as a way of corporate governance intervention, serve as a disciplining device to prevent managers from misbehavior. As such, clawback provisions need to be deterrent. Deterrent clawbacks increase the probability that an executive will have to return excess-pay resulting from errors in performance measures. They deter executives ex ante from misbehavior (such as overstating earnings) that causes excess-pay, and punish them ex post in case they do so. On the other hand, non-deterrent clawback provisions are more or less lacking in content. Companies adopt non-

\footnotetext{
${ }^{1}$ Sarbanes-Oxley Act of 2002, H. R. 3763, section 304, p. 34.
} 
deterrent provisions as a label under which they pretend to claw back excess pay, but they will presumably never do so.

Deterrent clawback policies provide an efficient mechanism to encounter (and reduce) the costs imposed on shareholders if executives would be allowed to keep the erroneously awarded compensation. They are of high practical relevance. From the optimal contracting's point of view, implementing a clawback mechanism brings the executive's compensation contract closer to an optimal or complete contract. Although there is no such thing as an optimal or complete contract, a clawback policy can solve the drawback resulting from compensation contracts that tie compensation to performance metrics that can be manipulated. Tying pay to performance encourages managerial slack that in turn makes compensation contracts less optimal. Explicitly implementing a recoupment arrangement makes managerial slack more costly and thus discourages future opportunistic behavior (Iskandar-Datta and Jia 2013).

In contrast to prior work, we focus on the firm-level heterogeneity in the structure of clawback policies and take a new perspective. We undertake a comprehensive linguistic analysis of each voluntary adopted clawback and explicitly recognize that firms have considerable discretion in how they design their policies. We do not treat the mere existence of a policy as a signal for a firm's commitment to claw back excess pay and thus to discipline managers. More specifically, we argue that clawback policies must be deterrent to serve as a disciplining mechanism and to bring compensation contracts closer to their optimal level. We provide examples for deterrent and non-deterrent provisions and argue that a deterrent clawback needs to satisfy the following two features: First, a provision should not incorporate any hurdles that reduce the likelihood of discovering a triggering event and second, it should obligate directors to claw back excess-pay in case the triggering event takes place. We derive those two features from Becker's (1968) prominent model of optimal public and private policies to combat illegal behavior. Based on this model, the most important decision variables are (i) the probability that misbehavior is discovered (first feature: the clawback is triggered), and (ii) the severity of the 
punishment or its enforcement (second feature: the obligation to recoup excess pay). Potential offenders (executives) who may consider to misbehave in order to boost their personal remuneration evaluate both factors before making a decision to violate the rules. If both features are implemented correctly, the clawback provision should deter managers from misbehavior. If, however, one feature lacks correct implementation, executives may be inclined to take the risk of misbehavior to benefit from the upside risk (boosting own compensation), while at the same time being less exposed to the downside risk (recoupment of excess pay).

In this paper, we construct a Deterrent index whose sub indices reflect the core elements of a clawback policy that do not include hurdles to recovery and discretion to forego recovery. Each sub index assesses the strength and deterrent effect of various dimensions that make up a clawback provision. These dimensions (and hence, sub indices) are: Trigger, Enforcement, Compensation-Coverage, Employee-Coverage, and Time-Period. We collected a sample of all Russell 3000 non-financial firms that initiated clawback provisions between 2007 and 2012. ${ }^{23}$ We then linguistically analyze each provision and assign each policy an index-value that captures its deterrent effect. The construction of the index itself is confirmed and supported by an explanatory factor analysis (EFA).

We linguistically analyze 3,578 clawback policies and show that these policies differ substantially across firms with regard to their deterrent effects. More specifically, the Deterrent index ranges from 1.22 to 6.33 with a mean (median) of 3.48 (3.46), and a standard deviation of 0.76, whereas higher values indicate less board discretion and a higher deterrent effect on executives. The statistics reveal that firms highly value the discretion whether or not to exercise their clawback powers. We demonstrate their discretion by providing extensive descriptive evidence on the various design choices that firms have when setting up their clawback provisions.

\footnotetext{
2 The Corporate Library does not list clawback provisions prior to 2007.

${ }^{3}$ We exclude non-financial firms since financial firms receiving funds under the Troubled Asset Relief Program (TARP) were obligated to implement a clawback provision in their executive compensation plans.
} 
Our conclusion on the heterogeneity of clawbacks is supported when we analyze each sub index separately.

Furthermore, we examine the impact of executives' incentives, executive power, corporate governance and firm characteristics on the deterrent level of voluntarily adopted clawbacks. Our results show that executive power, the executives' pay level, and weak corporate governance are associated with a low deterrent level. We also find that the deterrent level increases in directors' experience, firm profitability and management ownership. Our findings lend support to the notion that non-deterrent provisions are an outcome of powerful executives and weak corporate governance systems. If both come together, the provisions are not more than a label under which companies pretend to recoup excess pay, but will presumably never do so.

As one of the first paper to examine the deterrent effects of firm-initiated voluntary clawbacks, our study makes several contributions to the literature. First, our findings add to our understanding of firms’ voluntary use of corporate governance mechanisms by shedding light on the prevailing heterogeneity in clawback provisions across firms. We find that firms use their discretion by adopting low-deterrent policies that decreases the likelihood of recovery. Our results imply that we have to exercise caution when interpreting the effects of firm-level clawback provisions. The mere adoption of a clawback does not automatically imply a company’s commitment to recoup excess pay. Second, we linguistically analyze all voluntarily adopted clawbacks over the last six years to construct a deterrent measure. This allows us to provide evidence why some firms choose deterrent provisions and other firms do not. Finally, our study sheds light on the debate surrounding the practice of tying executive compensation to accounting measures of performance. Our results show that only certain clawback provisions can help reduce incentives to manipulate earnings arising from compensation considerations. In sum, our findings extend the literature on the voluntary use of corporate governance devices by documenting that firms prefer having the discretion to act. This has, of course, implications for 
other studies on clawback provisions that do not distinguish between low and high deterrent provisions.

The rest of the paper is organized as follows: Section 2 describes the existing clawback regimes and reviews prior literature on clawback provisions. Section 3 describes our Deterrent index, provides extensive empirical evidence on deterrent vs. non-deterrent provisions, and develops our testable hypotheses. Section 4 presents summary statistics of the index and our results from the multivariate analyses. Finally, Section 5 concludes.

\section{Regulatory Background and Literature Review}

\subsection{Regulatory and Theoretical Background}

Agency problems arising from a separation of ownership and control were first documented by Berle and Means (1932). They highlight the fact that the power over corporate assets is transferred to executives (agents) who do not consider wealth effects of the owners when they manage the firm. Agency theory and many researchers suggest the design of effective incentive compensation packages to align agents' and principals’ interests (Jensen and Murphy 1990, Mehran 1995). By tying pay to performance, incentive compensation serves as a device to provide sufficient incentives to executives to align their interests with those of shareholders, and thus reduces managerial opportunism (Hoskissen, Castleton and Withers 2009). However, compensation itself generates new agency problems at the expense of shareholders resulting in wealth shifting from shareholders to executives. Incentive compensation can encourage executives to report inflated performance figures and to commit fraud in an effort to increase their own compensation. From the principal agency theory's point of view, clawback provisions, as a way of corporate governance intervention, serve as a disciplining device to prevent managers from misbehavior. 
Deterrent clawback policies provide an efficient mechanism to encounter (and reduce) the costs imposed on shareholders if executives would be allowed to keep the erroneously awarded compensation. Excess-pay is very costly for shareholders in at least three ways: First, excess-pay reduces the amount of money that could have been otherwise allocated to shareholders or invested in the company on their behalf. Second, excess-pay - resulting randomly as in the case of accidental misreporting, or intentionally as in the case of executive misconduct - is not tied to the executive's performance. Thus, permitting executives to keep excess pay “[hurts] shareholders by undermining, and in some cases perverting, the desirable effects of incentive based compensation” (Fried and Shilon 2011). Allowing executives to keep compensation that is not related to firm performance decreases the pay-performance sensitivity and therefore destroys the major objective of incentive pay: The alignment between managerial incentives and shareholder wealth. Third, by committing misconduct to receive excess-pay (e.g. manipulating reported earnings) the executive destroys additional value (e.g. via higher tax payments) that likely exceeds the excess amount of value received by her. Based on a sample of 27 companies that have fraudulently inflated their earnings during the period 1996-2002, Erickson, Hanlon and Maydew (2004) find that the mean company paid an additional $\$ 11.84$ million in taxes on the inflated earnings. This amount represents 1.3 percent of the market value of the mean company. At the same time, the overstated earnings allowed executives to sell their shares at higher prices and to personally benefit from their misconduct.

Given the relevance of clawback provisions as a means to reduce costs of shareholders due to executives' misbehavior, it is not surprising that companies voluntarily started to install clawback policies in mid-2000 after the Enron Corp. and WorldCom Inc. scandals. On the regulatory side, the Sarbanes-Oxley Act (2002) was the first initiative to codify clawback policies. Section 304 of the Act required the CEO and the CFO of public companies to forfeit all types of incentive compensation and the profits realized from the sale of the company's securities, in the event of a restatement due to the material noncompliance stemming from misconduct. 
Following this provision, many large public companies started to adopt a formal clawback policy. This practice is now widespread: As of the end of 2012, 86.5\% of Fortune 100 companies have a clawback policy, up from 17.6\% in 2006 (Equilar 2013).

Moreover, Section 954 of the Dodd-Frank Wall Street Reform and Consumer Protection Act (signed into law in July 2010) requires publicly traded companies to adopt and implement a policy on the recovery of any incentive-based compensation on the basis of financial results that turn out to be erroneous and require a restatement (DFA clawback). ${ }^{45}$

There are a number of critical aspects in which the DFA clawback is superior to the SOX clawback. First, Section 954 places the burden of enforcement on corporate boards, whereas SOX 304 requires the SEC to enforce the forfeiture of erroneously awarded compensation.

Second, the DFA clawback does not require executive misconduct as a prerequisite for clawbacks. It prescribes a clawback policy in the event that "the issuer [company] is required to prepare an accounting restatement due to the material noncompliance of the issuer with any financial reporting requirement under the securities laws". ${ }^{6}$ SOX 304 states that recoupment of excess-pay shall be clawed back if the firm "is required to prepare an accounting restatement due to the material noncompliance of the issuer, as a result of misconduct". ${ }^{7}$ Although there have been thousands of restatements since 2002, the SEC exercised its clawback powers only a few times. This has been largely due to the ambiguous definition of misconduct, as SOX does not define the term "misconduct". Furthermore, SOX does not provide an answer to the question "whether a clawback can be triggered by the misconduct of any corporate employee, or only by misconduct on the part of a CEO or CFO” (Salehi and Marino 2008).

\footnotetext{
4 In addition to these provisions, Section 111 of the American Recovery and Reinvestment Act of 2009 imposes a compensation recovery requirement on financial institutions participating in the federal government's Troubled Asset Relief Program (TARP) for the period of TARP participation.

${ }^{5}$ In the absence of implementation rules that the SEC has yet to issue, the impact of this policy on corporate practices is vague.

${ }^{6}$ Dodd-Frank Act of 2010, H. R. 4173, section 954, p. 529.

${ }^{7}$ Sarbanes-Oxley Act of 2002, H. R. 3763, section 304, p. 34.
} 
Third, Section 954 covers more employees. It applies to executive officers in general and to former executives as well. Thus, executives have to fear a clawback even if they are not employees of the firm anymore. On the contrary, SOX 304 only applies to two executives, the current CEO and CFO.

Fourth, the DFA clawback reaches more years of compensation than SOX 304. It contains a look back period of three years before a firm is required to restate, whereas the latter only requires a period of one year following the first improper filing.

There is only one case in which the SOX clawback is superior to the DFA clawback: Section 954 only prescribes the recoupment of direct gains in the form of incentive-based compensation whereas the SOX clawback also requires the recovery of indirect gains such as profits from the sale of stocks. Thus, SOX 304 covers a larger recoverable amount.

\subsection{Literature Review}

Prior literature can be divided into studies that analyze the determinants of voluntary clawback adoption ("predict-clawback studies”) and those that examine whether the adoption has firm and capital-market effects (“effects-of-clawback studies”). Our study is placed in the third strand of literature that focuses on the deterrent effect of clawback policies.

\section{Predict-Clawback Studies}

Babenko, Bennett, Bizjak and Coles (2012) explore the likelihood of adopting a clawback provision. Their sample consists of S\&P 1,500 firms over the years 2000-2011. The authors report that executive malfeasance is a key determinant of voluntary clawback adoption: Firms are more likely to implement such provisions if i) there is prior executive malfeasance, ii) malfeasance is harder to detect, and iii) executives have more opportunities for malfeasance. Furthermore, they find that better corporate governance, measured by board independence, is positively associated with the adoption of a clawback. 
Brown, Davis-Friday and Guler (2013) find that the frequency of M\&A activity and goodwill impairments are the most significant determinants of a firm's decision to voluntarily adopt a clawback policy. Their analysis of 252 S\&P firms over 2005-2009 shows that M\&A announcement returns are larger for clawback-firms. Based on their findings, they conclude that clawbacks improve investors’ perception of the quality of M\&A transactions.

Chen, Greene and Owers (2013) analyze incentive properties with regard to clawback adoption. They test their model of contracting by examining clawback policies of over 1,000 large publicly traded firms from 2004 to 2011. Their results show that the incidence of clawback provisions is inversely related to firm risk, the noisiness of internal accounting information, and managerial risk aversion. They also find that clawback provisions are associated with higher CEO pay-performance sensitivity and reduced abnormal accruals.

\section{Effects-of-Clawback Studies}

Based on a sample of 281 firms that have a clawback provision in all years between 2007 and 2009 DeHaan, Hodge and Shevlin (2013) find that adopters improve their financial reporting quality, experience an improvement in investors' and analysts’ perceptions about their financial reporting quality, pay more total compensation, and compensate their executives more for performance.

Moreover, Babenko, Bennett, Bizjak and Coles (2012) show that the adoption of a clawback is associated with higher executive turnover. Based on a sample of 343 adopters from 2009, Chan, Chen, Chen and Yu (2012) find that adopting companies experience fewer accounting restatements and have a higher earnings-response-coefficient compared to nonadopters.

Based on the same sample Chan, Chen and Chen (2013) show that clawbacks improve financial reporting quality by assessing the impact of clawbacks on bank loans. Their results show that banks use more financial covenants and performance pricing provisions in their loan 
contracts and decrease interest rates after clawback adoption. In addition to that, they find that loan maturity increases and loan collateral decreases after firms initiate clawbacks.

Finally, Iskandar-Datta and Jia (2013) examine the impact of clawbacks of 246 firms during the 2005 - 2009 period on stock prices. They find, consistent with their argument that clawbacks mitigate financial reporting risk, that shareholders of adopting firms experience statistically significant positive stock-valuation consequences relative to propensity-scorematched control samples.

\section{Deterrent Effects of Clawback Provisions}

Our study is placed in the context of the third strand of literature that focuses on the deterrent effects of voluntarily adopted clawback policies. To the best of our knowledge, there exist only two studies examining the design of clawbacks. Both studies focus on small samples over a very short time period (one year). The first is Fried and Shilon (2011). Based on a sample of 225 S\&P 500 firms with clawback provisions in 2010, they report that $86 \%$ of their sample firms would not recoup excess pay unless the board made a finding of misconduct. The second is Lombardi (2011) who recognizes that the DFA clawback does not require firms to enforce their clawback provisions in all instances. Section 954 only demands companies to implement such policies.

Our study goes much further by taking a totally new perspective: We study whether clawbacks are designed to serve as a disciplining device (to deter managers from misbehavior) and to recoup excess-pay, or whether they mainly comprise of empty phrases that do not have any deterrent effects. We do so by focusing on the elements (words/ phrases/ sentences) of each provision. Our findings document that clawback policies differ substantially across companies in terms of their deterrent effects. We also identify the core components of deterrent provisions and analyze their determinants. 


\section{Sample, Index Construction and Hypotheses Development}

\subsection{Sample}

To assess the deterrent effect of voluntarily adopted clawback provisions, we collect a sample of companies that initiated the issuance of clawback provisions. The primary data source is the Corporate Library. From this database, we select all companies from the Russell 3000 that adopted a clawback provision between 2007 and 2012. ${ }^{8}$ The Corporate Library contains clawback provisions included in the proxy (DEF 14A) statements of Russell 3000 firms. ${ }^{\mathbf{9}, 10}$

Panel A of Table 1 shows that the Corporate Library reports 3,578 out of 14,651 firm-year observations with clawback provisions. ${ }^{11}$ This translates into an overall adoption rate of about $25 \%$ for the six years under study. We also observe that the rate of adopters increased significantly over time: In 2007 the adoption rate was as low as 12.07\% (269 out of 2,228 companies), increases to roughly 22\% in 2009 (562/2,614), and peaks at over 38\% in 2012 $(849 / 2,215)$.

To predict the deterrent effect of clawback provisions, we need corporate governance, executive compensation, and accounting data. We obtain data on firms’ corporate governance and ownership structure from the Corporate Library, data on executive compensation from ExecuComp and the Corporate Library, and financial data from Compustat. Due to data availability, our sample reduces to 2,118 firm-year observations for the multivariate analyses. ${ }^{12}$ Panels B and C of Table 1 detail our sample selection.

\section{- Insert Table 1 about here -}

\footnotetext{
${ }^{8}$ The Corporate Library does not list clawback provisions prior to 2007.

${ }^{9}$ We restrict ourselves to non-financial firms since financial firms receiving funds under the Troubled Asset Relief Program (TARP) were obligated to implement a clawback provision in their executive compensation plans.

${ }^{10}$ One might argue that analyzing clawback provisions included in the proxy statements is not sufficient. Compensation contracts of each executive could contain additional information that influences the deterrent effect of clawbacks. However, we only focus on publicly available information that can be easily accessed by any potential investor and analyst. Furthermore, firm policies that are publicly observable put firms under greater pressure to actually enforce them.

11 This corresponds to 1,195 unique firms.

12 This corresponds to 699 unique firms.
} 


\subsection{Index Construction}

\section{Linguistic Analysis}

To capture the deterrent effect of clawback provisions we develop a Deterrent index based on a novel linguistic analysis of 3,578 provisions. While screening the provisions we constantly had to answer the following question: Which words and phrases are important determinants of being a deterrent provision? Since the measurement of clawback deterrence is a complex exercise and involves subjective judgments, it is important to establish the validity of our construction procedure. We therefore involved many people in the index construction process. In the first step, each author read about 150 provisions very carefully to identify key words and phrases. We also employed two MBA students with a long-lasting practical experience in the consultancy industry. Based on another set of 300 provisions they came up with their own list of words and phrases. In the second step, we consolidated our findings and discussed this list with compensation consultants, lawyers, and colleagues. Based on these discussions we adjusted and revised our list of words and phrases in the third step. We then cross-checked this list with a randomized sample of another 300 provisions. In total, we manually analyzed about $25 \%(1,000)$ of all clawback provisions and obtained a list of about 1,500 words and phrases.

By taking into account related (finance, accounting and law) literature and our discussions with experts and colleagues, we identified five different dimensions of a clawback policy. They deal with the following questions: 1) What triggers the clawback?; 2) How is the clawback enforced?; 3) What compensation types are covered by the clawback?; 4) Which groups of employees are covered by the clawback?; and 5) What time period is covered by the clawback? All words and phrases from our screening procedure are next attributed to one of the five dimensions. They build the sub indices which reflect each dimension and which we label 1) Trigger, 2) Enforcement, 3) Compensation-Coverage, 4) Employee-Coverage, and 5) Time Period. Each sub index captures the deterrent effect of the underlying provision with regard to the 
dimension it represents. The higher the value of each sub index is, the more deterrent the provision is with regard to its dimensions.

To ease comparability and interpretation, we standardize each sub index and then transform it to a $[0 ; 1]$-interval. The final Deterrent index $(D E T)$ is then a weighted sum of these standardized and transformed sub indices (we explain the weighting procedure in section 3.3.) computed as follows:

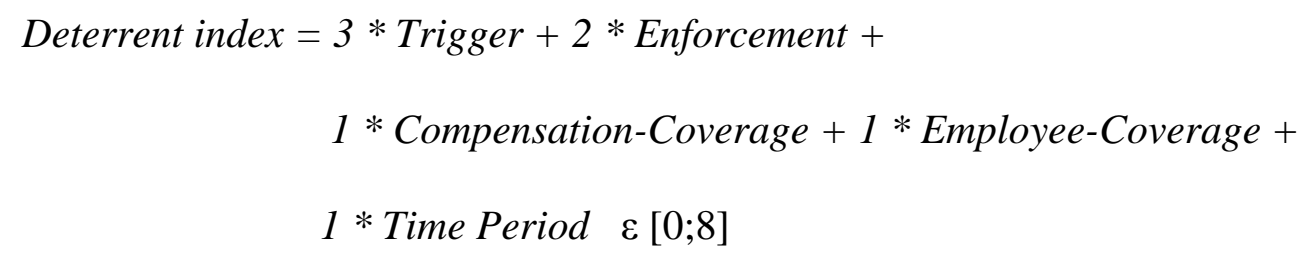

\section{Exploratory Factor Analysis}

To statistically assess the accuracy of the categorization of words and phrases into five dimensions and to support our linguistic analysis, we conduct an exploratory factor analysis (EFA). The EFA is based on the words and phrases obtained from our screening procedure. The most frequently used approach to determine the number of factors after an EFA is the KaiserGuttman criterion. It states that all factors with an eigenvalue greater than unity should be retained. However, this rule overestimates the number of latent factors. We therefore conduct a parallel analysis that generates a random dataset with the same numbers of observations and variables as the original data. We then compute the correlation matrix and eigenvalues (Matsunaga 2010). 16 factors (out of 42 obtained factors) with an eigenvalue greater than unity extracted from the original data are greater than the eigenvalues averaged over 1,000 replications in the parallel analysis. They characterize the dimensionality of the Deterrent index. The eigenvalues of the 16 factors range from 4.80 to 1.00 (mean $=1.57)$.

We use an oblique rotation method that allows the retained factors to be correlated in 
order to improve interpretability of the EFA solution. ${ }^{13}$ We associate each factor with those variables that have a loading in excess of 0.40 in absolute value which is a common practice in the literature (Larcker, Richardson and Tuna 2007, Ammann, Oesch and Schmid 2011). ${ }^{14}$

The resulting variables (reported by each sub index) that are associated with each factor are summarized in Panel A of Table 2. ${ }^{15}$ Most of the 16 factors are clearly defined by variables belonging to one of our five sub indices and confirm the construction of our index. Either a factor reflects one sub index (as it is the case for factors 2, 3 and 5 which correspond to the Compensation-Coverage, Trigger, and Employee-Coverage sub indices), or a factor reflects subdimensions of each sub index (as it is, for example, the case for factor 7 (and factors 10 to 16) which focuses on NEOs. Factor 7 is, therefore, a sub index of the sub index Employee-Coverage). Only five factors are hybrids, implying that the variables belong to different sub indices (factors $1,4,6,8,9)$. However, two out of these five hybrids actually represent one dimension: Factor 1 is made-up of three variables belonging to the sub index Enforcement (loadings between 0.64 and 0.87) and one variable belonging to the sub index Employee-Coverage with a relatively small factor loading (0.49). We therefore conclude that Factor 1 is mainly related to the sub index Enforcement. Factor 8 is also a hybrid as it is defined by one variable from the sub index Employee-Coverage (0.42), and one variable from the sub index Time-Period (0.99). Given the huge differences in factor loadings, this factor mainly reflects the sub index Time-Period.

To sum up, the EFA identifies a set of latent factors that are consistent with the sub indices of our Deterrent index. The EFA results strongly support our finding that clawback provisions are comprised of different dimensions reflected by (at least) five different sub indices.

\footnotetext{
${ }^{13}$ The best way to decide whether an oblique rotation is appropriate is to look at the factor correlation matrix. If the correlations are above 0.32, then there is enough overlap in variance among factors to warrant oblique rotation (Tabachnick and Fiddell 2007). This is the case for most of our correlation coefficients. Furthermore, any factor is to some extent related to other factors and thus oblique rotation enhances the interpretability of the EFA solution (Matsunaga 2010). We do not report the results of the parallel analysis and from the correlation matrix for the 16 factors to save space.

${ }^{14}$ Factor loadings are the weights and correlations between each variable and the factor. They lie between -1 and 1 . Higher loadings indicate a higher relevance of the variable in defining the factor.

${ }^{15}$ To save space, we only report results for the factors with the eight highest eigenvalues. Sections 3.3, 3.4 and 5.1 describe the variables in detail.
} 


\subsection{The Prominent Roles of the Sub Indices Trigger and Enforcement}

This section explains why we to put higher weights on the Trigger and Enforcement sub indices. We first explain their overall importance for the Deterrent index by giving examples of clawbacks with different realizations of both sub indices. Next, we corroborate our linguistic analysis on the importance of the two sub indices by applying i) Becker's (1968) model of optimal policies to combat illegal behavior, and ii) deterrence theory. Finally, we also run an EFA on all sub indices to statistically assess the accuracy of the weights.

\section{Linguistic Analysis}

In case an executive receives excess pay the company has to decide whether to recoup (part of) the compensation or not. The procedure for doing so is outlined in the clawback provision. The typical steps that have to be followed are as follows: First, the firm has to determine whether there has been an event that triggers the potential recoupment. These events are specified in the clawback text. Second, the clawback provision needs to lay down what should be done in case the triggering event took place. The provision can give discretion over the potential recoupment or it can require the recoupment without ambiguity. In the last step, the company determines what employee groups and which compensation types are affected, and over which time period the recoupment will have effect. These features are typically also specified in the provision.

\section{Trigger Sub Index}

As a first step, the firm has to determine whether there is a reason to recoup erroneously awarded compensation or not. We capture this by the Trigger index: 
Trigger (TR): The Trigger index captures the difficulty of proofing/determining whether a certain triggering event has occurred. Triggering events are, for instance, a financial restatement or a breach of a confidentiality agreement by an executive.

The occurrence of most triggering events is difficult to prove. Those events are considered to be hurdles for recovery. They prevent firms from using their clawback power. We identify and introduce three types of hurdles: The "misbehavior" hurdle, the "deliberateness" hurdle, and the “materiality" hurdle. The misbehavior hurdle refers to all kinds of detrimental conduct, such as fraud and misconduct. The deliberateness hurdle refers to all kinds of deliberate behavior, such as knowing and intentional behavior. The materiality hurdle refers to all characteristics signaling a severe event, such as substantial and material. ${ }^{16}$ With regard to the first two hurdles, boards will not claw back erroneously awarded compensation unless there is a finding of (deliberate) executive misbehavior. With regard to the third hurdle, boards have enough leeway to decide whether the triggering event is severe enough to cause the implementation of a clawback policy. Hence, executives can retain excess pay - regardless how large an amount - unless the firm determines that they have engaged in (deliberate) misbehavior (first and second hurdle), or that the triggering event was material enough (third hurdle).

Firms that have a misbehavior hurdle include such well-known companies as Northwest Pipe Company and IBM. Take a look at Northwest Pipe Company’s 2012 clawback provision:

"If the Company's financial statements are the subject of a restatement due to misconduct, [...], the Company will seek reimbursement of excess incentive cash compensation [...].”

\footnotetext{
${ }^{16}$ For example, the term "material noncompliance" - used in both the SOX 304 and the DFA clawback - leaves room for ambiguity. The term is neither defined in the statutes nor has the SEC addressed them so far. It is up to the company to decide whether noncompliance is material or not.
} 
Northwest Pipe Company obviously prevents itself from implementing its clawback provision absent a determination that the executive has engaged in misconduct that causes the restatement. Hence, the executive is the lucky one who is free to pocket her excess pay in case the board fails to prove misconduct. Among the 3,578 clawback policies, a full $62 \%$ explicitly include such a misbehavior hurdle that dilutes the deterrent effect of their recoupment policies.

By contrast, an Abercrombie \& Fitch executive is subject to a clawback whether or not she has committed misconduct. Consider Abercrombie \& Fitch’s 2012 clawback provision:

“[...] any such payment made to the participant must be repaid by such participant to the Company, without any requirement of misconduct on the part of the participant.”

Only $6 \%$ of our sample firms with policies do not require misbehavior on behalf of the executive to trigger the implementation of the clawback. The fact that the DFA clawback has removed the misconduct requirement - which is still part of the SOX clawback - stresses the importance of having no misbehavior hurdle. ${ }^{17}$

A lot of companies make it even harder to recover erroneously awarded compensation by adding the deliberateness hurdle to the misbehavior hurdle. Take a look at AOL's 2012 policy:

"The Company has adopted an Executive Compensation Recovery Policy pursuant to which, if the Company is required to prepare an accounting restatement [...] as a result of the intentional misconduct by an officer [...].”

The deliberateness hurdle reduces deterrence against misconduct as executives keep the portion of their compensation, unless the board determines that the misconduct was committed intentionally. Almost 34\% of our clawback observations include such a deliberateness hurdle.

\footnotetext{
${ }^{17}$ One might argue that the misconduct hurdle prevents innocent executives who are not responsible for e.g. the restatement from being punished. However, excess pay is that special part of the executive's incentive compensation that should not have been paid in any event as it is not tied to her performance.
} 
Even worse, Waste Management's, Inc 2009 clawback provision illustrates how a single company uses all three hurdles at once:

“[...] the policy allows the compensation committee to require reimbursement when there has been intentional or reckless conduct that caused financial results to materially increase an award or payment."

Waste Management. Inc. commits itself to recovering compensation from an executive only if the intentional misconduct materially increased an award. Neither misconduct nor intentional misconduct is sufficient for recovery. The committee also asks for a material increase in compensation. $60 \%$ of all 3,578 clawback observations include the materiality hurdle (but not necessarily in conjunction with the other two hurdles).

To sum up, all three hurdles - taken alone or together - prevent firms from dealing with the implementation of their clawback policies for at least two reasons: First, boards are likely to face difficulties in verifying that the triggering event has actually occurred. Second, boards can take advantage of their high level of discretion: They have sufficient leeway to decide that the triggering event was not severe enough to implement the clawback policy. The hurdles decrease the likelihood of a clawback substantially. Moreover, they make the remaining clawback features - such as the enforcement of a recoupment after being triggered, or the compensation amount that could be clawed back - redundant.

Based on the discussion above, the triggering event is key for an effective implementation of all remaining features of any clawback provision. Consequently, the sub index Trigger receives the highest weight in the final Deterrent index. 


\section{Enforcement Sub Index}

As a second step - after the triggering event has been determined - clawback policies contain a considerable amount of discretion over the enforcement of each provision. This discretion, which is an integral part of each provision, is captured by the Enforcement index.

Enforcement (EF): The Enforcement index focuses on the amount of discretion that is deliberately integrated in each provision. We capture this discretion by carefully analyzing the wording and phrasing of each policy.

A deterrent clawback policy should obligate directors to claw back excess-pay if the triggering event has occurred. This part of the clawback provision is very important, as directors are usually reluctant to punish managers. We offer three explanations for why directors are reluctant to enforce clawback policies. First, directors only own an infinitesimal small portion of the company's shares. Core, Holthausen and Larcker (1999) find that the median outside directors' stock ownership is only $0.005 \%$ of firm shares. Hence, directors usually do not enjoy noteworthy monetary benefits by clawing back excess compensation. Second, directors have personal reasons not to confront executives with a clawback. They tend to get along well with leading executives since those are able to exert influence over the directors re-nominating and reelection process. Finally, CEOs possess considerable influence and power outside the firms they manage. Thus, directors have strong incentives to maintain a friendly relationship with the CEOs they monitor since these managers can reward them in several beneficial ways.

Fried and Shilon (2011) argue, from a legal point of view, that it is very important to distinguish between verbs such as "may" or "must”. The choice of such words signals whether boards will exercise their clawback powers or not. Compensation consultants and lawyers designing the provisions and the directors revising them put emphasis on the language used. 
$48 \%$ of all 3,578 clawback observations contain phrases that explicitly give boards discretion to forego clawing back erroneously awarded compensation; 18\% contain phrases that only give the board the right to claw back implying that firms highly value the discretion emerging from their clawback policies. Consider, for example, Lexmark International's 2007 provision:

"[...], the Policy provides that the Company may recoup from such Covered Employees the excess incentive compensation [...].”

Lexmark International makes it quite clear that the board can decide whether to take corrective actions or not. In contrast to Lexmark International, the 2009 clawback provision of Belden Inc. obligates the CEO and CFO to forfeit excess pay:

"[...] Mr. Stroup, as CEO, and Mr. Benoist, as CFO, must forfeit certain bonuses and profits [...]. [...] the company, as permitted by law, will seek to recover any cash incentive compensation or other equity-based compensation [...].”

A clawback policy that obligates boards to clawback excess pay increases its deterrent effect significantly. It therefore follows that we weigh the sub index Enforcement with two. The sub index Trigger has a higher weight: This is due to the fact that it is a precondition of any clawback provision. The board needs to determine first whether a triggering event has occurred before deciding on the enforcement of the provision.

\section{Becker's (1968) Model and Deterrence Theory}

Our weighting process is corroborated by Becker's (1968) model and the deterrence theory. According to Becker's (1968) model of optimal policies to combat illegal behavior potential offenders take into account 1) the likelihood of detection, and 2) the severity of penalty 
before committing a felony. In Becker's model, a felony is similar to an economic activity in which positive and negative effects exist. The offender realizes a gain by, for example, stealing goods while the victim suffers a loss. The same framework applies to the principal agent framework in which opportunistic executives transfer wealth from shareholders to themselves. Based on Becker's analysis it is crucial to 1) increase the likelihood that a clawback is triggered, and 2) to enforce the policies with strength.

Similar to Becker (1968), the deterrence theory in criminology argues that a successful deterrent mechanism consists of three components: Certainty, severity and celerity. Certainty is the likelihood of detection and penalty. Severity corresponds to the magnitude of penalty, and celerity is the quickness with which a penalty is enforced (Gibbs 1975).

Based on Becker's analysis and deterrence theory we argue that a deterrent clawback policy should contain a triggering event that can be determined with certainty to increase the likelihood of its' detection. Furthermore, a deterrent clawback policy should also increase the likelihood of the enforcement of the penalty to increase its certainty, severity and celerity.

From this it also follows that we put higher emphasis on the Trigger and Enforcement index than on the remaining three sub indices.

\section{Exploratory Factor Analysis}

To further corroborate our weighting procedure, we conduct another EFA. Its purpose is to statistically assess the assigned weights for the Trigger and Enforcement sub indices.

After running a parallel analysis on all five sub indices we retain two factors and rotate them using oblique rotation. Panel B of Table 2 reports the factor loadings on each sub index. Factor 1 is clearly defined by the Compensation-Coverage (factor loading of 0.65), EmployeeCoverage (0.61) and Time-Period (0.70) sub index that are all weighted with one. Factor 2 is mainly defined by the Trigger (0.75) and Enforcement (0.55) sub index, both of which receiving 
high weights. ${ }^{18}$ The EFA results indicate that the sub indices defining Factor 2 are of similar importance for our Deterrent index and thus justify our weights (3 for Trigger, 2 for Enforcement) and the weights for the other three sub indices.

\subsection{Sub Indices Compensation-Coverage, Employee-Coverage and Time Period}

In a third step - given that the company has 1) successfully identified a triggering event, and 2) determined its enforcement -, clawback policies have to be constituted by various dimensions of a potential recoupment. These dimensions are reflected by three sub indices focusing on i) the kind of compensation that can be clawed back (Compensation-Coverage), ii) the employee groups that are covered (Employee-Coverage), and iii) the look-back period in which a firm can forfeit paid compensation (Time Period).

\section{Compensation-Coverage Sub Index}

The Compensation-Coverage index captures which parts of paid and/or deferred compensation are subject to a potential forfeiture. We screen the provisions for direct gains (e.g. cash payments, bonus payments) and indirect gains (profits from selling shares). Focusing only on the former is not sufficient since CEOs’ most significant profits typically arise from indirect gains (Ang, Cheng and Fulmer 2013). Covering both compensation types makes the provision more deterrent. We also take into account, for example, whether the forfeiture applies to longand/or short-term payments (time horizon), and other compensation features. To give an example, consider an extract of Lexmark International's, Inc. 2012 policy. It provides a detailed list of compensation types that are subject to recoupment:

"[...] the Company shall recoup (i) 100\% of the incentive compensation (annual bonuses, long-term incentive compensation, and performance-based equity awards) paid to the Covered Employee [...], and (ii) 100\% of the gains realized by the Covered Employee from the vesting and settlement of any restricted stock unit or other equity award or the vesting or exercise of any stock option, the sale of any stock acquired pursuant to the vesting and settlement of any restricted stock unit or any other equity award or the vesting

\footnotetext{
${ }^{18}$ Although the sub index Time-Period has a loading of 0.51 , it rather describes Factor 1 . Its loading is much higher for Factor 1 (0.70) and smaller relative to the loadings on Trigger and Enforcement.
} 
and exercise of any stock option, and all cash awards [...]. In addition, the Policy requires the Covered Employee to forfeit any vested and unvested stock options, restricted stock units and any other equity awards. [...] “

\section{Employee-Coverage Sub Index}

The Employee-Coverage index focuses on the various employee groups and/or individuals that are affected by the clawback policy. A deterrent provision does not only cover the current CEO and CFO of a given company (as regulated under SOX 2002), but also its NEOs, its directors, its executives, and at best even former employees. Consider, as an example, Canadian National Railway Company’s 2009 policy. It explicitly covers all current and former executives:

"Under this policy, which applies to all executives, the Board may, in its sole discretion, [...], require reimbursement [...]. The Board of Directors may seek reimbursement of full or partial compensation from an executive or former executive officer [...]"

\section{Time Period Sub Index}

The Time-Period index distinguishes clawback provisions in terms of their look-back period. The look-back period specifies how far a company can go back in time to recoup the compensation that was paid to its employees during this period. A longer look-back period makes a policy more deterrent since there is always a time lag between the detection of the triggering event and the payment of the corresponding excess compensation. Consider, as an example Kulicke \& Soffa Industries', Inc. 2010 policy. This policy contains a look-back period of five years, which is extremely long compared to the mean look-back period (12 months):

“[...] Under the recoupment policy, the Company may seek to recover or recoup incentive awards that were paid or vested up to 60 months prior to the date the applicable restatement is disclosed." 


\subsection{Hypotheses Development and Variables}

If clawback provisions serve as a disciplining device to deter managers from misbehavior, the question arises as to why firms allow these policies to include hurdles and allow boards to forego recoupment. We offer two primary explanations: First, managers have incentives to oppose the adoption of a deterrent provision. Second, managers have power and influence over (weak) boards that make it very difficult for directors to implement compensation arrangements that executives disapprove.

\section{Managerial Incentives}

The very basic premise of the agency theory suggests that managers have strong incentives to influence the deterrent level of clawback policies to decrease the likelihood of recovery. The repayment of previously paid or allocated compensation appears to be a negative gain and thus a loss to the executive. While fully supported by the agency theory, this prediction is also consistent with the prospect theory; a loss creates a greater disutility to the individual compared to the utility of an equivalent monetary gain. The Kahneman-Tversky value function is generally steeper for negative changes in wealth (losses) than for positive changes (gains) (Kahneman and Tversky 1979). In line with Kahneman and Tversky (1979) the endowment effect proposed by Kahneman, Knetsch and Thaler (1991) states that people value a good more once they own it. In other words, the repayment of a portion of previously paid or owned compensation creates a greater feeling of pain to the executive than her knowledge that she will not receive this amount of money at all.

Based on the above line of reasoning we expect that executives have stronger incentives to oppose a deterrent provision if their compensation level is high. Higher pay levels likely imply a higher recoupment of erroneously awarded remuneration and thus a higher disutility to executives. 
Hypothesis 1 (Executives' Incentives): The executives' incentive to adopt a lowdeterrent clawback is positively related to the level of their total compensation.

We proxy for total compensation via Executives' Pay Slice, which is the sum of the base salary, bonus, option grants, and all other compensation of the top three executives scaled by the three years moving average EBIT. Executives' pay slice is also a proxy for the relative importance and power of the top three executives as well as their ability to extract rents.

\section{Executive Power}

Executives have influence over boards that make it very difficult for directors to adopt deterrent clawback policies. According to the skimming view and the managerial power approach, powerful executives have essential bargaining power and thus determine their own compensation arrangements (Bertrand and Mullainathan 2000, Bertrand and Mullainathan 2001, Bebchuk and Fried 2004). A clawback policy can be seen as a part of an executive's compensation arrangement as its structure is jointly determined with other aspects of executive compensation. Our second hypothesis predicts:

Hypothesis 2 (Executive Power): Firms with powerful CEOs and executives tend to adopt low-deterrent clawbacks.

We employ three proxies for executives’ power and their ability to influence the deterrent level of clawback policies. The first one is the CEO pay slice - the fraction of the three years moving average aggregated amount of base salary, total non-equity incentive and bonus compensation of the top three executive team captured by the CEO. ${ }^{19} \mathrm{CEO}$ pay slice can also be interpreted as the relative importance and power of the CEO as well as her ability to extract rents.

\footnotetext{
${ }^{19}$ In contrast to Bebchuk, Peyer and Cremers (2011), we do not include option grants in our computation since we focus on the realized and relative compensation in order to make more accurate comparisons among the top-five executives.
} 
We expect firms with a high CEO pay slice to have a less deterrent policy. Our second proxy is the log of CEO tenure (CEO Tenure). Consistent with Hill and Phan (1991) we argue that tenure provides a CEO with enough time to establish powerful influence over the board of directors and therefore to tie her compensation arrangements more closely to her own preferences. As a result, we hypothesize that the deterrent level of a firm's clawback provision will decline with tenure. Finally, we measure managerial power by examining whether the CEO is also the chairman of the board of directors (CEO Chair). A CEO who also serves as the chairman of the board is more powerful and will use her power to tie her compensation more closely to her own preferences. Thus, we expect firms in which the CEO serves also as the board chair to adopt a low deterrent provision.

\section{Internal Corporate Governance}

Complementary to Hypothesis 2, we argue that weak internal corporate governance reduces the likelihood of adopting a deterrent clawback. The empirical findings of Bertrand and Mullainathan (2001) support this view. They show that CEOs have more power over their compensation arrangements when corporate governance is weak.

Hypothesis 3 (Weak Internal Corporate Governance): Firms with weak internal corporate governance tend to adopt low-deterrent clawbacks.

We capture the internal corporate governance structure by the two years moving average total number of all directors on a given board (Board Size) and the two years moving average percentage of directors with more than four corporate directorships (Busy Directors).

We use board size as a proxy for weak governance as smaller boards carry out their monitoring duties more effectively than larger boards. Larger groups generally suffer from coordination and decision making problems (Yermack 1996). The influence of busy directors on the deterrent level of clawbacks is less clear. On the one hand, one can argue that busy directors 
are considered as less effective monitors since they suffer from time constraints due to their multiple memberships. Directors sitting on too many boards overcommit themselves and may shirk their monitoring duties. ${ }^{20}$ On the other hand, busy directors can also be regarded as effective monitors since they are a source of valuable experience and knowledge with regard to managerial oversight (Haunschild 1993, Haunschild and Beckman 1998). The empirical findings of prior literature on the effect of busy directors are mixed. Based on a sample of 508 companies over 1989 and 1995, Fich and Shivdasani (2006) find that firms in which a majority of outside directors have three or more board memberships are associated with weak corporate governance and weak firm performance. These companies have lower market-to-book ratios, weaker profitability, and lower sensitivity of CEO turnover to firm performance. Ferris, Jagannathan and Pritchard (2003) also examine the effect of busy directors on firm performance on a sample of 3,190 firms from 1995. In contrast to Fich and Shivdasani (2006), they find no evidence that busy directors harm firm performance.

\section{Profitability}

The skimming view argues that the ability of managers to influence their compensation arrangements is higher when the company is doing well. Good performance provides executives with extra leeway. Managers would try to enforce better arrangements for themselves since shareholders do not monitor firms as closely as during bad periods. In other words, when the firm is performing well, shareholders are less likely to notice a non-deterrent clawback provision.

Hypothesis 4 (Profitability): Corporate profitability is negatively associated with the deterrent level of clawbacks.

We use EBITDA scaled by assets (Profitability) as a measure of corporate profitability.

\footnotetext{
${ }^{20}$ For example, “overcommitted directors might serve less frequently on important board committees such as the audit or the compensation committees (Ferris, Jagannathan and Pritchard 2003).
} 


\section{Top Management Ownership}

As property rights become dispersed, the power over corporate assets is more and more concentrated in the executives rather than in the owners' hands: An "ownership of wealth without appreciable control and control of wealth without appreciable ownership” (Berle and Means 1932) prevails leading to a divergence of interests between the owners and executives. As "managers are not substantially affected by the wealth effects of their actions" (Fama and Jensen 1983) they have incentives to pursue their own self-serving interests. Jensen and Meckling (1976) argue that higher management ownership increases the alignment of interests between owners and management. According to the convergence-of-interest hypothesis (Morck, Shleifer and Vishny 1988) managers would pay a larger share of the costs emerging from their selfserving behavior. As a result, they make decisions that are not solely advantageous for them but also for the firm they co-own. This line of reasoning also applies to the members of the board of directors. They pursue their monitoring duties more carefully as their ownership rises since they have to pay a larger share of the costs resulting from managerial misconduct.

In line with the convergence-of-interest hypothesis, we expect that higher management ownership (sum of executive and board ownership) is associated with more deterrent clawback provisions.

Hypothesis 5 (Management Ownership): The deterrent level of a clawback increases as management ownership rises.

We use the fraction of outstanding shares held by the top management team and directors as a measure of management ownership (Management Ownership).

\section{Research Design and variables}

Companies self-select into voluntary clawback adoption. We account for the self-selection problem by estimating a Heckman two stage model with a probit model for the selection equation 
and an OLS regression in the second stage. We add the inverse Mills' ratio (IMR) (obtained from the selection equation) to the second stage model and use panel data on corporate governance, compensation characteristics and other covariates to estimate the following equations:

Clawback $=\alpha+\mathrm{z}_{1}$ Industry Adoption $+\beta_{1}$ Executives' Pay Slice $+\beta_{2}$ CEO Pay Slice

$+\beta_{3}$ CEO Tenure $+\beta_{4}$ CEO Chair $+\beta_{5}$ Busy directors $+\beta_{6}$ Board size

$+\beta_{7}$ Profitability $+\beta_{8}$ Management Ownership

$+\Sigma \beta_{\mathrm{k}}$ Control Variables $+\Sigma \beta_{\mathrm{k}}$ (Industry and Year) $+\varepsilon$

Deterrent Index $\quad=\alpha+\mathrm{z}_{1}$ IMR $+\beta_{1}$ Executives' Pay Slice $+\beta_{2}$ CEO Pay Slice

$+\beta_{3}$ Tenure $+\beta_{4}$ CEO Chair $+\beta_{5}$ Busy directors $+\beta_{6}$ Board size

$+\beta_{7}$ Profitability $+\beta_{8}$ Management Ownership

$+\Sigma \beta_{\mathrm{k}}$ Control Variables $+\Sigma \beta_{\mathrm{k}}$ (Industry and Year) $+\varepsilon$

The dependent variable in the first stage, Clawback, is a binary variable equal to 1 if the company has a clawback and 0 otherwise. The dependent variable in the second stage is the Deterrent index, a proxy for clawback deterrence given that companies have adopted a clawback. All independent variables of interest are as described in section 3.5 and Appendix I.

Many firm characteristics are potentially associated with the adoption and deterrent effect of clawback provisions while at the same time being also associated with governance and compensation characteristics of firms. We therefore include an extensive set of control variables. We control for the readability of each clawback provision via the Fog index. The Fog index became increasingly popular in the academic literature over the past years (see, e.g., (Li 2008, Lehavy, Li and Merkley 2011). ${ }^{21}$ We further control for Peer Litigation (fraction of class action lawsuits by other firms in the same 2-digit SIC c ode industry), Firm complexity (R\&D expenditures scaled by total assets), Leverage (long term debt and debt in current liabilities divided by the book value of debt and the market value of the firm), Liquidity (current book

\footnotetext{
${ }^{21}$ The Fog index is well-known and simple to compute by capturing text complexity as a function of syllables per word and words per sentence. For our sample of clawback provisions the average Fog index is about 33, which would require a formal education of 33 years. Note that clawback provisions are developed by highly-educated experts (lawyers, compensation consultants) and that they target a small and equally highly educated and specialized audience.
} 
assets minus inventories divided by current liabilities), Share Return (one year share return), Size (log of total book assets), Tobin's $Q$ (book value of long-term debt and debt in current liabilities plus market cap divided by book assets), Firm Growth (three-year geometric growth in sales), and Audit Committee Size (two years moving average total number of audit committee members). We also include industry and year fixed-effects (Industry 2-digit SIC code and Year) to control for macroeconomic effects and to reduce concerns of cross-sectional correlated residuals. We cluster standard errors by firm to mitigate serial correlation. All significance levels discussed below are based on two-tailed tests.

An important feature of the Heckman model is the exclusion restriction: we need to identify a variable that is correlated with clawback adoption but that does not affect the choice of the deterrent level of the adopted clawback provision (Larcker and Rusticus 2010, Lennox, Francis and Wang 2012). Several studies examine the determinants of clawback adoption (Addy, Chu and Yoder 2009, Babenko, Bennett, Bizjak and Coles 2012, Chan, Chen, Chen and Yu 2012). The main consensus emerging from these studies is that firm size is an important determinant of clawback adoption. However, firm size does not fulfill the exclusion restriction, as it is also a determinant of the structure of clawback policies. ${ }^{22}$ Instead, we identify Peer Adoption as an appropriate instrument and add it to the selection equation. Peer Adoption is calculated as the percentage of peer firms in the same 2-digit SIC code industry that has already adopted a clawback before the specific firm adopts a clawback. We do not expect a relationship between this variable and the Deterrent index. ${ }^{23}$ We argue that companies tend to adopt clawbacks when such provisions are prevalent among their peers. Thus, we hypothesize a positive relationship between Peer Adoption and Clawback Adoption.

In addition to our Heckman model, we also estimate a Tobit model as robustness test. We

\footnotetext{
${ }^{22}$ Firm size is a common proxy for firm complexity. Furthermore, larger firms are associated with more monitoring from creditors. Thus, we cannot rule out that firm complexity is not related to the structure of clawback provisions.

${ }^{23}$ Note that Peer Adoption is not the average deterrent level of a firm's peers in the same industry, but the percentage of peer firms that already have adopted a clawback.
} 
aim to find that the results do not differ from our Heckman model. We also add non-clawback adopters to our Tobit model. For these firms, we set the Deterrent index to zero. This procedure is not problematic as the smallest value of the index is 1.22 .

\section{Empirical findings}

\subsection{Descriptive Statistics of Clawback Provisions}

Panel A of Table 3 reports descriptive statistics of the Deterrent index, each of its sub indices, and the readability measures (Fog index, number of words). Panel B highlights the change of those variables over time; Panel C reports detailed summary statistics for all components of each sub index. Table 4 shows correlation matrices for the components of each sub index. Table 5 provides summary statistics of each independent variable.

- Insert Tables 3, 4 and 5 about here -

\section{Deterrent Index}

Panels A and B of Table 3 reveal the prevailing heterogeneity of clawback provisions with regard to their deterrent effect. The Deterrent index ranges from 1.22 to 6.33 with a mean of 3.48, a median of 3.46, and a standard deviation of 0.76 . It starts at 3.45 in 2007 and moderately increases to 3.55 in 2012. Panel B illustrates that the Deterrent index and its sub indices did not really change over time, implying a degree of stickiness in the structure of clawback provisions.

Consider Cypress Semiconductor Corporation’s 2011 clawback provision as an example for having a low Deterrent index:

“In November 2011, we adopted a clawback policy under which our named executive officers may be required, subject to the committees' discretion, to return incentive compensation payments to us if (i) he or she engaged in intentional misconduct pertaining to any financial reporting policy, (ii) there is a material negative revision of a financial or operating measure on the basis of which incentive compensation was awarded or paid to the employee, or (iii) he or she engaged in any fraud, theft, misappropriation, embezzlement or dishonesty." 
This provision has the smallest index-value (1.22) which is driven by i) a Trigger index of 0 ii) a small Enforcement index of 0.32, iii) an Employee-Coverage index of 0.46, iv) a CompensationCoverage index of 0.11, and v) a Time-Period index of 0. Consider next Bon-Ton Stores', Inc. 2010 policy as an example for a high deterrent provision:

“[...] the board adopted in 2010 a recoupment policy applicable to annual cash incentive awards, performance-based restricted stock and other performance-based compensation to executive officers of the company. The policy provides that in the event the company is required to prepare an accounting restatement due to the company's noncompliance with any financial reporting requirement under the securities laws, the company shall take action to recoup from executive officers the amount by which such awards exceeded the payment that would have been made based on the restated financial results. Compensation subject to recoupment will include equity or contingent income exercised, earned or distributed during the periods, not to exceed three years that required restatement of financial statements. [...]”

This provision lies in the 99\% percentile of the Deterrent-index and has a value of 5.9 Its high deterrent effect is driven by i) a Trigger index of 0.7 ii) a very high Enforcement index of 1.0, iii) an Employee-Coverage index of 0.46 (sample mean), iv) a Compensation-Coverage index of 0.66, and v) a Time Period index of 0.75. Although Bon-Ton Stores’ policy does not score the highest value in each sub index, it belongs to the top $1 \%$ of all provisions. This is because each sub-index - except the Employee-Coverage-index - lies at least in the top 95\% percentile of the sample distribution.

\section{Trigger Sub Index}

Panels A and B of Table 3 show that the unstandardized Trigger index ranges from -5 to 5 with a mean of -0.46 , a median of 0 , and a standard deviation of 1.52 . The standardized and transformed Trigger index has a mean of 0.45 , a median of 0.50 , and a standard deviation of 0.15 . The overall small mean of 0.45 (minimum value $=0$, maximum value $=1$ ) indicates that firms 
value the discretion to determine whether to trigger a clawback or not. There is not much - if any - change in the Trigger index over time: its mean rests at an average of 0.46 .

Panel C of Table 3 indicates that only 10\% of all provisions do not include any hurdle (misbehavior, deliberateness, materiality), making it more difficult for $90 \%$ of the sample boards' to determine whether a triggering event took place or not. Panel C also reveals that firms change the composition of triggering events included in their provisions. On average, $81 \%$ (equals 2,907 provisions) of all clawback observations include a financial restatement as a triggering event over the period 2007-2012. This figure went up from just $67 \%$ in 2007 to more than $87 \%$ in 2012. A financial restatement is a non-discretionary event requiring no assessment on part of the board. Thus, it should trigger a clawback in any case. However, the correlation matrix (Panel A of Table 4) shows positive and highly significant correlations between the financial restatement trigger and i) the misbehavior hurdle $(0.15, \mathrm{p}$-value $<0.01)$ and ii) the materiality hurdle $(0.22$, p-value $<0.01)$. Hence, a restatement is sufficient to trigger a clawback without the requirement of misbehavior and/ or materiality for only $14 \%$ (500 provisions) of all clawback provisions (not displayed in Table 3). In the remaining 2,407 (2,907-500) provisions the restatement trigger is linked to the misbehavior and/ or materiality hurdle.

Other events that trigger a potential clawback include financial misstatements (37\%; up from 20\% in 2007 to 47\% in 2012), breach of post-employment agreements (17\%; down from $23 \%$ in 2007 to $12 \%$ in 2012), termination for cause (7\%; down form $11 \%$ in 2007 to $4 \%$ in 2012), and criminal behavior (7\%). The materiality hurdle is contained in nearly $60 \%$ and the deliberateness hurdle in nearly $34 \%$ of all policies. This let us conclude that most firms prefer discretionary triggers.

The following two provisions give examples for clawbacks with a very low and a very high Trigger sub index. Consider first, Hibbett Sports’, Inc. 2010 clawback provision: 
“[...] the Company could seek recoupment [...] if it is determined that the senior executive engaged in fraud, willful misconduct, recklessness or gross negligence that caused or otherwise significantly contributed to the need for a material restatement [...]”

The Trigger-value of this provision belongs to the $1 \%$ percentile. The company has to overcome the misbehavior (misconduct, negligence), deliberateness (willful, recklessness), and materiality (gross, significantly, material) hurdle in order to eventually recoup excess compensation. Given this formulation, it is very unlikely that the board will ever implement its policy; it is more or less “cheap talk”. Consider, on the other hand, Nielsen Holdings’ N.V. 2010 policy:

“[...] we recover all or a portion of any bonus [...] upon the occurrence of a breach of noncompetition, confidentiality or other restrictive covenants that may apply to a participant, or the restatement of our financial statements [...] as a consequence of errors, omissions, fraud, or misconduct [...]”

Nielsen Holdings’ Trigger-value belongs to the 99\% percentile. The policy offers a variety of non-discretionary events that trigger a potential clawback (breach of noncompetition, confidentiality or other restrictive covenants). There is no hurdle to overcome. The same applies to the restatement trigger: Although misconduct contains the misbehavior hurdle per definition, the restatement can also be a consequence of errors or omissions.

\section{Enforcement Sub Index}

The descriptive statistics of the Enforcement index reveal that most policies grant boards discretion to forego recovery and thus do not bond them to recoup excess pay. Panel A and B of Table 3 show that the unstandardized Enforcement index ranges from -21 to +10 with a mean of 3.13, a median of -4 , and a standard deviation of 6.25 . The standardized and transformed Enforcement index has a mean of 0.58 , a median of 0.55 and a standard deviation of 0.20 . Like the Trigger index, the Enforcement index hardly changes over time. Its overall low deterrence level remains stable. 
Panel C of Table 3 indicates that half of the policies contain words and phrases that signal an obligation to recoup excess pay (52\% of all observations). However, the number of provisions signaling an obligation declines sharply over time from more than $61 \%$ in 2007 to only 50\% in 2012. Companies may have had good intentions when they introduced clawback provisions for the first time in 2007. The sharp decline over the years is very likely due to managers' aversion to deterrent provisions. Notwithstanding this decline, the overall fraction of "obligating policies" seems to be high. This has to be put in perspective: more than $18 \%$ of all observations contain words indicating that the board only has a right to claw back, but no obligation. Moreover, 48\% include words or phrases signaling a lot of discretion concerning a potential recoupment. ${ }^{24}$ In addition to that, $71 \%$ of all obligating policies also contain phrases indicating weak clawback actions, such as "in its sole discretion", or "based on the boards judgment". These phrases attenuate the meaning of the obligating phrases, and - in certain cases - make them even meaningless. The correlation matrix (Panel B of Table 4) supports this line of reasoning: policies pointing to strong clawback actions typically coincide with weak clawback actions (correlation of 0.43, p-value $<0.01)$. In addition, phrases indicating an obligation to claw back also refer to weak actions (correlation $=0.19$, p-value $<0.01$ ). This reveals that firms value the discretion whether or not to exercise their clawback powers. The following provision illustrates how a single company obligates its board to claw back while giving it discretion to take actions at the same time (Bunge Limited, 2009):

"[...] the Board or committee shall take such actions as it deems appropriate to remedy the misconduct and prevent its recurrence. [...]

As highlighted in the text, the "board or committee shall take such actions as it deems appropriate". Taking these two phrases together, there is no real obligation to recoup excess pay.

\footnotetext{
${ }^{24}$ Please note that these percentages do not sum up to $100 \%$ : $48 \%$ of all policies contain words and/or phrases signaling both an obligation and a right to or having discretion to claw back (figures not reported).
} 
It is all in the board's discretion, even though the policy instructs the board to claw back. Consider next a policy indicating strong enforcement, i.e. the board will definitely recoup excess pay (Thor Industries, Inc., 2012):

“[...] the Company will seek recoupment [...]. This newly-adopted clawback policy does not require fault or malfeasance by any employee before compensation must be repaid. It simply requires repayment of any incentive-based compensation [...].”

\section{Compensation-Coverage Sub Index}

Panels A and B of Table 3 show that the unstandardized Compensation-Coverage index ranges from 0 to 9 with a mean of 3.10, a median of 3 , and a standard deviation of 1.73 . The standardized and transformed Compensation-Coverage index has a mean of 0.34 , a median of 0.33 and a standard deviation of 0.19 .

Panel C of Table 3 indicates that the majority of all policies cover incentive compensation in general (97\%). 55\% of all provisions explicitly include direct profits through stock options or stocks in general (cash) in a recoupment. Only $21 \%$ of all provisions also recoup indirect compensation (e.g. gains from selling shares). ${ }^{25}$

\section{Employee-Coverage sub index}

Panel A and B of Table 3 show that the unstandardized Employee-Coverage index ranges from 2 to 15 with a mean of 8.14, a median of 8.00, and a standard deviation of 2.32. The standardized and transformed Employee-Coverage index has a mean of 0.47, a median of 0.46 and a standard deviation of 0.18 . There is some variation in the Employee-Coverage index over time: its mean increases monotonically from 0.42 in 2007 to 0.49 in 2012 . Obviously, more and more employees became subject to a potential recoupment over the years.

\footnotetext{
${ }^{25}$ Please note that all percentages do not sum up to $100 \%$ : provisions can refer to multiple compensation types and/or features.
} 
Panel C of Table 3 indicates that the majority of all policies refer to executives in general when deciding on which employees to cover under their provisions (88\%). Those provisions are relatively vague and intangible. Out of these provisions, 21\% explicitly cover all executives, no matter of their precise positions in the firm. $7 \%$ also cover all former employees. They offer the most rigorous employee coverage. Focusing on specific positions within a firm, most provisions explicitly mention NEOs (24\%), CEOs (8\%), and CFOs (6\%). Panel C reveals that companies either prefer referring to employee groups (such as NEOs, executives in general, all executives), or to specific individuals (such as CEO, CFO, president, other).

\section{Time-Period Sub Index}

Panels A and B of Table 3 show that the unstandardized Time-Period index ranges from 1 to 5 with a mean of 1.61 , a median of 1 , and a standard deviation of 1.14 . The standardized and transformed Time-Period index has a mean of 0.15 , a median of 0 , and a standard deviation of 0.29. There is some variation in the Time-Period index over time: its mean increases monotonically from 0.09 in 2007 to 0.18 in 2012. Obviously, firms became more stringent and cover a longer time period over the years.

\section{Summary}

In sum, the descriptive statistics of firm-level clawbacks reveal considerable heterogeneity across clawback provisions, recognizing that firms have substantial flexibility in how they design their provisions. In light of descriptive evidence we find that there are major differences in the deterrence level of firms’ provisions. Our findings in Tables 3 and 4 are important because they are inconsistent with the notion that voluntary adopted clawbacks signal a firm’s commitment to clawback excess-pay. They also highlight the fact that one has to exercise caution when interpreting the results of prior studies on the effect of clawback provisions. 


\subsection{Univariate Analysis}

Panel A of Table 5 presents descriptive statistics for the dependent and independent variables included in the second stage of the Heckman model. ${ }^{26}$ Before estimating the multivariate Heckman and Tobit model to test our hypotheses outlined in section 3, we first present t-test statistics for differences in means of firms belonging to the lower $10 \%$ quintile (low deterrent level) and upper 10\% quintile (high deterrent level). According to Panel B of Table 5, we find that $C E O$ Tenure is higher for firms with low deterrent provisions compared to firms with high deterrent provisions (mean of 7.555 (=5.40 years) vs. mean of 7.354 (4.30 years). ${ }^{27}$

Consistent with our expectations regarding the weak corporate governance hypothesis we find that Board Size (18 vs. 17 directors) is significantly higher for firms with less deterrent clawbacks. The fraction of Busy Directors (1.70\% vs. $2.30 \%)$ is higher in firms belonging to the upper $10 \%$ percentile suggesting that the importance of deterrent clawbacks are more pronounced in firms in which directors suffer from time constraints. The variable Management Ownership captures the percentage of outstanding shares held by the top management team and directors. The fraction of Management Ownership (6.20\% vs. 9.70\%) is significantly smaller in firms with low deterrent provisions indicating that higher ownership is associated with better alignment of interests.

- Insert Table 5 about here -

\subsection{Multivariate Analyses}

\section{Heckman regression}

To control for a potential self-selection problem associated with the adoption of clawback provisions, we estimate a Heckman-two-stage regression. Columns 1 and 2 of Table 6 report our estimated coefficients of the Heckman model. We also present regression results of a Tobit

\footnotetext{
${ }^{26}$ We do not report descriptive statistics for variables included in the first stage model to save space. Furthermore, this study primarily serves to examine the determinants of the deterrent level of clawbacks.

${ }^{27}$ Note that the variable CEO Tenure is defined as the natural logarithm of the number of days in office.
} 
specification in column 3. All regressions contain industry and time fixed-effects and standarderrors clustered at the firm level. ${ }^{28}$

We add the inverse Mills' ratio (IMR) obtained from the selection model (column 1) to the second stage equation (column 2) to control for the self-selection problem associated with clawback adoption. The statistically significant $I M R(-0.183$, p-value $<0.05)$ implies that selection problem is apparent in this model and suggests that its inclusion is necessary, and as a result it would have been incorrect to estimate the second stage equation using OLS. The negative sign of the coefficient indicates that OLS would produce downwardly biased estimates. More importantly, we find that clawback adoption is positively associated with the instrumental variable Peer Adoption (3.345, p-value < 0.01). Firms tend to implement a clawback policy if its industry peers do so.

Focusing first on the selection equation in Column 1, we find that clawback adoption is positively associated with Peer Adoption, Board Size, Firm Size, and Profitability. The adoption decision is negatively associated with Leverage, Management Ownership, and Sales Growth. These results are in line with prior findings.

Concerning the main equation of interest presented in Column 2, we find support for our first hypothesis. The executives' incentive hypothesis states that adopting a low-deterrent clawback is positively related to executives’ compensation levels. The variable Executives’ Pay Slice is negatively related to the Deterrent index and significant at the $10 \%$-level (t-value $=-1.80)$. Hence, executives who receive more pay do not endorse high deterrent clawbacks.

The second hypothesis (Executive Power) predicts that powerful executives try to use their influence in order to adopt only low deterrent provisions. We proxy for CEO power by CEO Tenure, CEO Pay Slice, and by CEO Chair. We expect to obtain negative coefficients on all variables. The data partly confirms our predictions. Although all coefficients are negative, they are not significant at conventional levels. However, the statistically significant and negative

\footnotetext{
${ }^{28}$ Since our aim is not to explain changes in the deterrent-level within each firm over time, we do not include firmfixed effects.
} 
coefficient on Executives' Pay Slice supports our line of reasoning. Similar to Bebchuk, Cremers and Peyer (2011), this variable also measures the executives’ power to extract rents.

In line with hypothesis 3 (Weak Internal Corporate Governance) the variable Board Size captures a significant coefficient (t-value=-2.62). Firms with larger boards are likely to have a lower value of the Deterrent index. Jensen (1993) already pointed out that larger boards are less likely to carry out their monitoring role effectively and are easier for the CEO to control. We find a positive and significant coefficient on busy directors (t-value=2.63) suggesting that directors with more managerial oversight prefer deterrent provisions. One could argue that directors suffering from time constraints prefer deterrent clawbacks as these policies act as a strong monitoring device permitting directors to spend less time on their monitoring duties.

Inconsistent with our fourth hypothesis (Profitability) that predicts a negative relationship between profitability and the deterrent level of clawbacks, we find a positive coefficient (tvalue=1.74) suggesting that firms with higher cash flow are more likely to use more deterrent provisions, as the scope for executive malfeasance is larger. Another explanation for the positive coefficient is based on the assumption that good corporate governance affects profitability. Thus it may be strong governance that indirectly influences the design of clawback policies through profitability.

Finally, we find that the deterrent level increases with Management Ownership (tvalue=2.51). Executives and boards are more willing to support policies that benefit the firm if they bear personal costs resulting from executive misbehavior.

\section{Robustness Checks}

Following the suggestions by Lennox, Francis and Wang (2012), we compute the variance inflation factors (VIFs) for the Heckman model. We only find one instance of VIF equal 6.51 and find no instances of VIF's greater than 3.48, suggesting that multicollinearity is unlikely a 
concern in our analysis. Nevertheless, we also estimate the main equation using a Tobit model (column 3). Our results are similar to the Heckman model.

\section{- Insert Table 6 about here -}

\section{Conclusion}

We construct a Deterrent index with five sub indices (Trigger, Enforcement, Compensation-Coverage, Employee-Coverage, and Time-Period) capturing the core elements of a clawback policy that obligates boards to recoup erroneously awarded compensation. We argue that deterrent clawback policies disavow directors the discretion to forego recovery and thus obligating the implementation of a clawback. To assess the deterrent effect of voluntary adopted clawback provisions and to construct our Deterrent index, we conduct a linguistic analysis of 3,578 clawback provisions.

In sum, our results strongly imply that voluntary adopted clawbacks are on average not an adequate governance mechanism. Companies highly misuse the discretion to design their clawback policies according to their own needs. We observe a huge heterogeneity in terms of the deterrent effects of clawback provisions. While some policies can be considered to improve corporate governance and discipline managers, other clawback policies are more or less boilerplate disclosure. They do not provide guidelines according to which boards have to recoup excess pay. Moreover, they gave boards discretion over exercising their supervisory roles. One may argue that leaving the decision to recoup excess pay entirely to the board could be in the best interest of shareholders. There exists, however, despite hundreds of cases in which managers misbehaved to enrich themselves at the cost of shareholders, and only a few cases in which the board (or the SEC) has enforced a recoupment. Executives are typically not required to return excess pay, although clawback provisions are in place. We therefore conclude that for the majority of firms voluntarily adopted clawbacks only pretend to act as a disciplining device to protect shareholders. This situation calls for more stringent standards and regulation. 
In further analysis we provide explanations for the observed heterogeneity of clawbacks: The provisions are less deterrent if executives have strong incentives to keep excess-pay, if corporate governance is weak, and if executives are powerful. Furthermore, we find that the deterrent level increases with firm profitability and management ownership. These findings are in line with our explanations above.

As one of the first papers to examine the deterrent effect of firm-initiated voluntary clawbacks, our study identifies the core elements of a deterrent clawback provision and implies that we have to exercise caution when interpreting the effects of firm-level clawback provisions. The distribution of our Deterrent index indicates that the mere adoption of a clawback does not automatically signal a company’s commitment to recoup excess-pay. Unfortunately, most firmlevel clawbacks are not designed to clawback excess-pay; they are more or less "cheap talk”. 


\section{References}

Addy, N. D., X. Chu and T. R. Yoder (2009). "Recovering Bonuses After Restated Financials: Adopting Clawback Provisions." Mississippi State University working paper.

Ammann, M., D. Oesch and M. M. Schmid (2011). "Corporate governance and firm value: International evidence." Journal of Empirical Finance 18(1): 36-55.

Ang, J., Y. Cheng and S. Fulmer (2013). "Clawing Back Executive Compensation." Florida State University working paper.

Babenko, I., B. Bennett, J. M. Bizjak and J. L. Coles (2012). "Clawback Provisions." Arizona State University working paper.

Bebchuk, L. and J. Fried (2004). Pay without Performance: The unfulfilled promise of executive compensation. Cambridge, Massachussets, Harvard University Press.

Bebchuk, L. A., K. J. M. Cremers and U. C. Peyer (2011). "The CEO Pay Slice." Journal of Financial Economics 102(1): 199-221.

Becker, G. S. (1968). "Crime and Punishment: An Economic Approach." Journal of Political Economy 76: 169-217.

Berle, A. A. and G. Means, C. (1932). The Modern Corporation and Private Property. New York, Macmillan.

Bertrand, M. and S. Mullainathan (2000). "Agents with and without principals." The American Economic Review 90(2): 203-308.

Bertrand, M. and S. Mullainathan (2001). "Are CEOs rewarded for luck? The ones without principals are." The Quarterly Journal of Economics 116(3): 901-932.

Brown, A. B., P. Y. Davis-Friday and L. Guler (2013). "M\&A Activity and the Voluntary Adoption of Clawback Provisions in Executive Compensation Contracts." City University of New York working paper.

Chan, L. H., K. C. W. Chen, T.-Y. Chen and Y. Yu (2012). "The Effects of Firm-initiated Clawback Provisions on Earnings Quality and Auditor Behavior." Journal of Accounting and Economics 54(2-3): 180-196.

Chen, M. A., D. Greene and J. Owers (2013). "The Costs and Benefits of CEO Clawback Provisions." Working Paper

DeHaan, E., F. Hodge and T. Shevlin (2013). "Does Voluntary Adoption of a Clawback Provision Improve Financial Reporting Quality?" Contemporary Accounting Research.

Erickson, M., M. Hanlon and E. L. Maydew (2004). "How much will firms pay for earnings that do not exist? Evidence of taxes paid on allegdly fraudulent earnings." The Accounting Review 79(2): 387-408. 
Fama, E. F. and M. C. Jensen (1983). "Separation of Ownership and Control." Journal of Law and Economics 26(2): 301-325.

Ferris, S. P., M. Jagannathan and A. C. Pritchard (2003). "Too Busy to Mind the Business? Monitoring by Directors with Multiple Board Appointments." The Journal of Finance IVIII(3): 1087-1111.

Fich, E. M. and A. Shivdasani (2006). "Are Busy Directors Effective Monitors?" The Journal of Finance LXI(2): 689-724.

Fried, J. and N. Shilon (2011). "Excess-Pay Clawbacks." The Journal of Corporation Law 36 (4): 721-751.

Haunschild, P. R. (1993). "Interorganizational Imitation: The impact of interlocks on Corporate Acquistion Activity." Administrative Science Quarterly 38: 564-592.

Haunschild, P. R. and C. M. Beckman (1998). "When Do Interlocks Matter: Alternate Sources of Information and Interlock Influence." Administrative Science Quarterly 43: 815844.

Hill, C. W. L. and P. Phan (1991). "Ceo Tenure as a Determinant of Ceo Pay." Academy of Management Journal 34(3): 707-717.

Hoskissen, R. E., M. W. Castleton and M. C. Withers (2009). "Complementarity in Monitoring and Bonding- More Intense Monitoring Leads to Higher Executive Compensation." Academy of Management Perspectives: 57-74.

Iskandar-Datta, M. and Y. Jia (2013). "Valuation Consequences of Clawback Provisions." The Accounting Review 88(1): 171-198.

Jensen, M. C. (1993). "The Modern Industrial Revolution, Exit, and the Failure of Internal Control Systems." The Journal of Finance 48: 831-880.

Jensen, M. C. and W. H. Meckling (1976). "Theory of the Firm: Managerial Behavior, Agency Costs and Ownership Structure." Journal of Financial Economics 3(4): 305-360.

Jensen, M. C. and K. J. Murphy (1990). "Performance Pay and Top-Management Incentives." The Journal of Political Economy 98(2): 225-264.

Kahneman, D., J. L. Knetsch and R. H. Thaler (1991). "Anomalies The Endowmenet Effect, Loss Aversion, and Status Quo Bias." Journal of Economic Perspectives 5(1): 193-206.

Kahneman, D. and A. Tversky (1979). "Prospect Theory: An Analysis of Decision under Risk." Econometrica 47(2): 263-292.

Larcker, D. F., S. A. Richardson and I. Tuna (2007). "Corporate Governance, Accounting Outcomes, and Organizational Performance." The Accounting Review 82(4): 963-1008.

Larcker, D. F. and T. O. Rusticus (2010). "On the use of instrumental variables in accounting research." Journal of Accounting and Economics 49(3): 186-205. 
Lehavy, R., F. Li and K. Merkley (2011). "The Effect of Annual Report Readability on Analyst Following and the Properties of Their Earnings Forecasts." The Accounting Review 86(3): 1087-1115.

Lennox, C. S., J. R. Francis and Z. Wang (2012). "Selection Models in Accounting Research." The Accounting Review 87(2): 589-616.

Li, F. (2008). "Annual report readability, current earnings, and earnings persistence." Journal of Accounting and Economics 45(2-3): 221-247.

Lombardi, S. R. (2011). "Interpreting Dodd-Frank Section 954: A Case for Corporate Discretion in Clawback Policies." Columbia Business Law Review 2011(3:881): 881-917.

Matsunaga, M. (2010). "How to Factor-Analyze Your Data Right: Do s, Don ts, and How-To s." International Journal of Psychological Research 3(1): 97-110.

Mehran, H. (1995). "Executive Compensation Structure, Ownership, and Firm Performance." Journal of Financial Economics 38: 163-184.

Morck, R., A. Shleifer and R. W. Vishny (1988). "Management Ownership and Market Valuation." Journal of Financial Economics 20: 293-315.

Morgenson, G. (2013). "Clawbacks? They're Still a Rare Breed." The New York Times. Salehi, N. H. and E. A. Marino (2008). "§304 of Sarbanes-Oxley Act: New tool for disgorgement?" New York Law Journal.

Yermack, D. (1996). "Higher market valuation of companies with a small board of directors." Journal of Financial Economics 40(2): 185-211. 


\section{Appendix I}

\section{Description of variables}

\begin{tabular}{|c|c|c|}
\hline Variable & Description & Data source \\
\hline \multicolumn{3}{|c|}{ Firm-specific variables } \\
\hline Clawback & Binary variable equal to one for clawback adopters & Corporate Library \\
\hline $\begin{array}{l}\text { Deterrent } \\
\text { Index }\end{array}$ & $\begin{array}{l}\text { Weighted sum of five standardized and [0;1]- } \\
\text { transformed sub-indices }(3 * \text { Trigger }+2 * \text { Enforcement } \\
+ \text { Compensation-Coverage }+ \text { Employee-Coverage }+ \\
\text { Time-Period). Each sub index is based on a linguistic } \\
\text { and factor analysis of firms' clawback provisions } \\
\text { obtained from the Corporate Library. It measures the } \\
\text { deterrent effect of each provision. The larger the } \\
\text { index, the more deterrent a provision is. }\end{array}$ & Own computation \\
\hline $\begin{array}{l}\text { Firm } \\
\text { Complexity }\end{array}$ & $\begin{array}{l}\text { Research \& development expenditures divided by } \\
\text { book assets }\end{array}$ & Compustat \\
\hline Fog Index & $\begin{array}{l}\text { Measures the readability of English writing. The } \\
\text { index estimates the years of formal education needed } \\
\text { to understand the text on a first reading. It is } \\
\text { calculated as follows: Fog }=(\text { words per sentence }+ \\
\text { percent of complex words) } * 0.4 \text {, where complex } \\
\text { words are defined as words with three syllables or } \\
\text { more. }\end{array}$ & Own computation \\
\hline$I M R$ & Inverse Mills Ratio & Own computation \\
\hline Industry & 2-digit SIC codes & Compustat \\
\hline Leverage & $\begin{array}{l}\text { Long term debt and debt in current liabilities divided } \\
\text { by the book value of debt and market capitalization of } \\
\text { the firm. }\end{array}$ & Compustat \\
\hline Liquidity & $\begin{array}{l}\text { Current book assets minus inventories divided by } \\
\text { current liabilities; } \\
\text { winsorized at } 1 \%\end{array}$ & Compustat \\
\hline $\begin{array}{l}\text { Peer } \\
\text { Adoption }\end{array}$ & $\begin{array}{l}\text { Fraction of peer clawback-firms in the same 2-digit } \\
\text { SIC code industry before the specific firm adopts a } \\
\text { clawback }\end{array}$ & Corporate Library \\
\hline $\begin{array}{l}\text { Peer } \\
\text { Litigation }\end{array}$ & $\begin{array}{l}\text { Fraction of class action lawsuits by other firms in the } \\
\text { same 2-digit SIC code industry }\end{array}$ & $\begin{array}{l}\text { Securities Class } \\
\text { Action } \\
\text { Clearinghouse } \\
\text { database }\end{array}$ \\
\hline Profitability & EBITDA divided by book assets & Compustat \\
\hline Sales Growth & Three-year geometric growth in sales & Compustat \\
\hline Share Return & One year share return; winsorized at $1 \%$ & Compustat \\
\hline Firm Size & Log of total book assets & Compustat \\
\hline Tobin’s $Q$ & $\begin{array}{l}\text { Book value of long-term debt and debt in current } \\
\text { liabilities plus the market capitalization of the firm } \\
\text { divided by book assets }\end{array}$ & Compustat \\
\hline Year & Indicator variables for each year & Compustat \\
\hline
\end{tabular}




\begin{tabular}{|l|l|l|}
\hline \multicolumn{3}{|c|}{ Governance variables } \\
\hline $\begin{array}{l}\text { Audit } \\
\text { Committee }\end{array}$ & $\begin{array}{l}\text { Two years moving average total number of audit } \\
\text { committee members }\end{array}$ & Corporate Library \\
\hline Board Size & $\begin{array}{l}\text { Two years moving average total number of all } \\
\text { directors on a given board }\end{array}$ & Corporate Library \\
\hline $\begin{array}{l}\text { Busy } \\
\text { Directors }\end{array}$ & $\begin{array}{l}\text { Two years moving average fraction of directors with } \\
\text { more than four corporate directorships }\end{array}$ & Corporate Library \\
\hline CEO Chair & $\begin{array}{l}\text { Indicator variable whether the CEO is also chairman } \\
\text { of the board }\end{array}$ & Corporate Library \\
\hline CEO Tenure & Log of CEO tenure & Execucomp \\
\hline $\begin{array}{l}\text { Management } \\
\text { Ownership }\end{array}$ & $\begin{array}{l}\text { Fraction of outstanding shares held by the top } \\
\text { management team and directors }\end{array}$ & Execucomp \\
\hline
\end{tabular}

\begin{tabular}{|l|l|l|}
\hline \multicolumn{3}{|c|}{ Executive Compensation variables } \\
\hline $\begin{array}{l}\text { CEO Pay } \\
\text { Slice }\end{array}$ & $\begin{array}{l}\text { Fraction of the three years moving average } \\
\text { aggregated amount of base salary, total non-equity } \\
\text { incentive and bonus compensation of the top three } \\
\text { executive team captured by the CEO }\end{array}$ & Execucomp \\
\hline $\begin{array}{l}\text { Executives’ } \\
\text { Pay Slice }\end{array}$ & $\begin{array}{l}\text { Sum of the base salary, bonus, option grants, and all } \\
\text { other compensation of the top three executives scaled } \\
\text { by the three years moving average earnings before } \\
\text { taxes and income }\end{array}$ & Execucomp \\
\hline
\end{tabular}




\section{TABLE 1}

\section{Clawback adoption rates and sample selection}

Panel A presents the number of firms that voluntarily adopted a clawback provision between 2007 and 2012. Panel B details our sample selection. Panel C details the sample selection for our multivariate analyses.

Panel A: Clawback adoption rates of non-financial firms

\begin{tabular}{l|l|llllll} 
& $2007-$ & & & & & & \\
& 2012 & 2007 & 2008 & 2009 & 2010 & 2011 & 2012 \\
\hline Companies with a clawback & 3,578 & 269 & 399 & 562 & 717 & 782 & 849 \\
Total number of companies & 14,651 & 2,228 & 2,749 & 2,614 & 2,468 & 2,377 & 2,215 \\
Adoption rate (in \%) & 24.42 & 12.07 & 14.51 & 21.50 & 29.05 & 32.90 & 38.33 \\
Change in adoption rate (in \%) & & & +2.44 & +6.99 & +7.55 & +3.85 & +5.43
\end{tabular}

Panel B: Sample composition for the multivariate analyses I ( $1^{\text {st }}$ stage Heckman and Tobit model)

Number of clawback adopters with available data $\quad 2,118$

\begin{tabular}{ll} 
Number of non-clawback adopters with available data & 3,811 \\
\hline Final sample for multivariate analysis I* & 5,929
\end{tabular}

* Corresponds to 1,359 unique firms

Panel C: Sample composition for the multivariate analyses II ( $2^{\text {nd }}$ stage Heckman)

Total number of clawback provisions over 2007-2012* 4,835

Exclusion of financial firms $-1,257$

Sub-total 3,578

\begin{tabular}{ll} 
Elimination of observations with missing data & $-1,460$ \\
\hline Final sample for multivariate analysis II** & 2,118
\end{tabular}

* Corresponds to 1,195 unique firms

** Corresponds to 699 unique firms 
TABLE 2

Exploratory factor analysis (EFA)

Factors are computed using EFA. We retain all factors that have an eigenvalue both greater than unity and greater than the eigenvalues averaged over 1000 replications in the parallel analysis. Panel A reports factor loadings on variables inferred from the screening procedure for each of the 8 factors (reported by each sub index) after an oblique rotation. We do not tabulate the results of the parallel analysis and only report factors with the eight highest eigenvalues to save space. We retain variables where the absolute value of the factor loading exceeds 0.40. Loadings exceeding 0.40 in absolute value are in bold. Sub indices are abbreviated with TR for Trigger, EF for Enforcement, CC for Compensation Coverage, EC for Employee Coverage and TP for Time Period. Panel B reports factor loadings when conducting an EFA on the sub indices. All variables related to our indices are as explained in sections 3.3, 3.4 and 5.1 of the paper.

\section{Panel A: Rotated factor loadings on all variables}

\begin{tabular}{l|llllllll}
\hline Variable & Factor 1 & Factor 2 & Factor 3 & Factor 4 & Factor 5 & Factor 6 & Factor 7 & Factor 8 \\
\hline TR Financial Restatement & 0.25 & 0.07 & 0.05 & 0.16 & 0.06 & 0.19 & 0,13 & -0.03 \\
TR Termination for Cause & 0.03 & -0.06 & 0.07 & -0.06 & -0.04 & 0.22 & 0,01 & 0.14 \\
TR Poor Performance & -0.05 & 0.06 & 0.01 & 0.01 & -0.05 & 0.05 & $-0,03$ & -0.04 \\
TR No Restatement & -0.09 & -0.02 & -0.05 & -0.20 & 0.03 & 0.90 & $-0,18$ & -0.11 \\
TR No Hurdle & 0.27 & -0.03 & 0.03 & -0.27 & 0.01 & $\mathbf{0 . 4 0}$ & 0,23 & -0.12 \\
TR Misbehavior & 0.22 & 0.10 & $\mathbf{0 . 6 5}$ & 0.01 & 0.00 & -0.09 & $-0,09$ & -0.02 \\
TR Materiality & 0.14 & -0.01 & $\mathbf{0 . 4 4}$ & 0.07 & 0.00 & -0.06 & 0,12 & 0.01 \\
TR Fraudulent Behavior & 0.03 & -0.04 & 0.70 & 0.03 & -0.01 & 0.04 & 0,17 & -0.10 \\
TR Financial Misstatement & 0.16 & -0.11 & -0.03 & 0.06 & 0.16 & 0.13 & 0,12 & -0.14 \\
TR Early Departure & 0.01 & -0.03 & 0.00 & 0.07 & -0.01 & 0.20 & $-0,03$ & 0.12 \\
TR Deliberateness & 0.05 & -0.10 & $\mathbf{0 . 8 4}$ & -0.12 & -0.02 & -0.09 & 0,07 & -0.01 \\
TR Criminal Behavior & -0.29 & -0.06 & $\mathbf{0 . 5 7}$ & 0.08 & 0.01 & 0.09 & $-0,01$ & 0.05 \\
TR Breach of Post-Empl. Agreements & 0.07 & 0.13 & -0.12 & 0.05 & 0.00 & -0.11 & 0,17 & -0.02 \\
\hline
\end{tabular}




\begin{tabular}{l|llllllll}
\hline Variable & Factor 1 & Factor 2 & Factor 3 & Factor 4 & Factor 5 & Factor 6 & Factor 7 & Factor 8 \\
\hline EF Words Indicating that the Board is & 0.23 & 0.14 & -0.10 & -0.10 & 0.03 & -0.06 & 0.09 & 0.28 \\
Obligated to Claw Back & & & & & & & & \\
EF Words Indicating that the Board has & $\mathbf{0 . 6 4}$ & 0.07 & 0.02 & 0.06 & 0.05 & 0.11 & 0.14 & 0.00 \\
$\begin{array}{l}\text { Discretion to Claw Back } \\
\text { EF Phrases Signaling Weak Clawback }\end{array}$ & $\mathbf{0 . 8 5}$ & -0.01 & 0.07 & -0.10 & 0.02 & -0.17 & 0.05 & -0.06 \\
$\begin{array}{l}\text { Actions } \\
\text { EF Phrases Signaling Strong Clawback }\end{array}$ & $\mathbf{0 . 8 7}$ & -0.09 & -0.02 & -0.12 & -0.13 & -0.10 & 0.38 & -0.08 \\
Actions & & & & & & & & \\
EF Words Indicating that the Board Has \\
the Right to Claw Back & -0.17 & 0.25 & 0.05 & -0.12 & -0.09 & 0.02 & -0.14 & -0.16 \\
\hline CC Time Horizon & -0.10 & 0.01 & -0.03 & $\mathbf{0 . 9 5}$ & -0.11 & -0.15 & $-0,04$ & -0.08 \\
CC Stocks and Stock Options & 0.05 & $\mathbf{0 . 8 5}$ & -0.05 & -0.04 & -0.02 & 0.02 & 0,10 & 0.03 \\
CC Stock Option Features & 0.03 & $\mathbf{0 . 8 4}$ & -0.08 & 0.08 & -0.09 & 0.00 & 0,02 & -0.01 \\
CC Other Compensation Features & -0.06 & $\mathbf{0 . 6 5}$ & 0.06 & -0.14 & -0.03 & -0.07 & $-0,11$ & -0.07 \\
CC Other Compensation & 0.09 & -0.04 & -0.08 & 0.17 & -0.08 & 0.00 & 0,20 & -0.23 \\
CC Incentive Compensation & 0.37 & 0.17 & 0.02 & 0.29 & -0.03 & 0.12 & 0,07 & 0.07 \\
CC Direct Profits: Stock Gains & -0.10 & $\mathbf{0 . 5 7}$ & 0.02 & 0.02 & 0.18 & 0.03 & $-0,02$ & 0.01 \\
CC Cash Compensation & 0.03 & 0.12 & 0.19 & 0.05 & 0.03 & 0.08 & 0,22 & 0.05 \\
\hline
\end{tabular}




\begin{tabular}{l|llllllll}
\hline Variable & Factor 1 & Factor 2 & Factor 3 & Factor 4 & Factor 5 & Factor 6 & Factor 7 & Factor 8 \\
\hline EC Explicitly: Other Individuals & 0.33 & 0.22 & 0.01 & -0.11 & 0.24 & -0.01 & $-0,22$ & -0.01 \\
EC Explicitly: NEO & -0.16 & 0.04 & 0.10 & -0.06 & 0.04 & -0.14 & $\mathbf{0 , 9 1}$ & 0.15 \\
EC Explicitly: Former Employees & 0.00 & -0.02 & -0.07 & 0.02 & -0.07 & 0.24 & 0,06 & $\mathbf{0 . 4 2}$ \\
EC Explicitly: COO & -0.02 & 0.00 & 0.13 & 0.02 & 0.06 & -0.01 & $-0,05$ & 0.01 \\
EC Explicitly: CFO & -0.07 & -0.03 & 0.00 & -0.09 & $\mathbf{0 . 9 5}$ & 0.02 & 0,04 & 0.00 \\
EC Explicitly: CEO & -0.06 & -0.04 & -0.02 & -0.02 & $\mathbf{0 . 9 5}$ & 0.02 & 0,02 & 0.02 \\
EC Explicitly: CAO & 0.03 & -0.06 & -0.04 & -0.06 & 0.06 & -0.15 & $-0,06$ & 0.05 \\
EC Explicitly: All Executives & -0.01 & 0.00 & 0.04 & 0.32 & 0.10 & 0.23 & $-0,38$ & 0.09 \\
EC Explicitly: (Vice) President & 0.11 & -0.14 & -0.07 & $\mathbf{0 . 5 4}$ & 0.19 & -0.22 & $-0,01$ & -0.07 \\
EC Executives in General & $\mathbf{0 . 4 9}$ & 0.16 & 0.11 & 0.21 & -0.13 & 0.07 & $-0,15$ & 0.11 \\
\hline TP Specified Date & 0.02 & -0.03 & -0.04 & -0.19 & 0.05 & 0.14 & 0.09 & -0.10 \\
TP Shorter/Equal 6 Months & -0.07 & 0.00 & -0.04 & -0.09 & 0.02 & -0.18 & 0.14 & $\mathbf{0 . 9 9}$ \\
TP Shorter / Equal 36 Months & -0.20 & 0.08 & -0.09 & 0.17 & -0.02 & 0.56 & 0.05 & -0.17 \\
TP Shorter / Equal 24 Months & -0.08 & 0.19 & -0.01 & 0.10 & 0.06 & -0.12 & 0.38 & -0.11 \\
TP Shorter / Equal 12 Months & -0.10 & 0.14 & 0.01 & 0.01 & 0.09 & -0.08 & -0.14 & -0.05 \\
TP Longer Than 36 Months & 0.05 & 0.12 & -0.02 & 0.13 & 0.03 & 0.01 & 0.16 & 0.05
\end{tabular}

Panel B: Rotated factor loadings on the sub indices

\begin{tabular}{l|ll} 
Variable & Factor 1 & Factor 2 \\
\hline Sub Index Trigger (Standardized and Transformed) & 0.09 & $\mathbf{0 . 7 5}$ \\
Sub Index Enforcement (Standardized and Transformed) & -0.17 & $\mathbf{0 . 5 5}$ \\
Sub Index Compensation-Coverage (Standardized and Transformed) & $\mathbf{0 . 6 5}$ & -0.14 \\
Sub Index Employee-Coverage (Standardized and Transformed) & $\mathbf{0 . 6 1}$ & -0.13 \\
Sub Index Time Period (Standardized and Transformed) & $\mathbf{0 . 7 0}$ & $\mathbf{0 . 5 1}$
\end{tabular}




\section{TABLE 3}

\section{Descriptive statistics}

Panel A presents summary statistics of the Deterrent index, each of its sub indices, and the readability measures (Fog-index, number of words). Panel B presents the change of those variables over time; Panel C reports detailed summary statistics for all components of each sub index. The Deterrent index consists of five sub-indices: Trigger, Enforcement, Compensation-Coverage, Employee-Coverage, and Time-Period. We construct each sub index by summing up indicator variables. We then standardize (stand) each sub index and transform (trans) it to a [0,1]-interval. The final Deterrent-index is computed as a weighted sum of these standardized and transformed variables:

Deterrent-index $=3 *$ Trigger $+2 *$ Enforcement $+1 *$ Compensation-Coverage $+1 *$ Employee-Coverage $+1 *$ Time Period.

\section{Panel A: Index descriptics}

\begin{tabular}{l|llllll} 
Variable & Obs. & Mean & Std. Dev. & Min & Median & Max \\
\hline Deterrent Index & 3578 & 3.48 & 0.76 & 1.22 & 3.46 & 6.33 \\
Trigger & 3578 & -0.46 & 1.52 & -5 & 0 & 5 \\
Trigger (Stand. \& Trans.) & 3578 & 0.45 & 0.15 & 0 & 0.5 & 1 \\
Enforcement & 3578 & -3.13 & 6.25 & -21 & -4 & 10 \\
EF (Stand. \& Trans.) & 3578 & 0.58 & 0.2 & 0 & 0.55 & 1 \\
Employee-Coverage & 3578 & 8.14 & 2.32 & 2 & 8 & 15 \\
EC (Stand. \& Trans.) & 3578 & 0.47 & 0.18 & 0 & 0.46 & 1 \\
Compensation-Coverage & 3578 & 3.1 & 1.72 & 0 & 3 & 9 \\
CC (Stand. \& Trans.) & 3578 & 0.34 & 0.19 & 0 & 0.33 & 1 \\
Time Period & 3578 & 1.61 & 1.14 & 1 & 1 & 5 \\
TP (Stand. \& Trans.) & 3578 & 0.15 & 0.29 & 0 & 0 & 1 \\
Fog-Index & 3540 & 33.15 & 10.22 & 13.27 & 30.7 & 140.75 \\
Number of Words & 3540 & 143.59 & 85.97 & 12 & 126 & 834
\end{tabular}


Panel B: Change over time

\begin{tabular}{l|lllllll} 
Year & $\begin{array}{l}\text { Deterrent } \\
\text { Index }\end{array}$ & Trigger & $\begin{array}{l}\text { Trigger } \\
\text { (Stand. \& } \\
\text { Trans.) }\end{array}$ & Enforcement & $\begin{array}{l}\text { EF (Stand. \& } \\
\text { Trans.) }\end{array}$ & $\begin{array}{l}\text { Employee- } \\
\text { Coverage }\end{array}$ & $\begin{array}{l}\text { EC (Stand. \& } \\
\text { Trans.) }\end{array}$ \\
\hline 2007 & 3.45 & -0.33 & 0.47 & -2.25 & 0.60 & 7.46 & 0.42 \\
2008 & 3.41 & -0.44 & 0.46 & -3.21 & 0.57 & 7.77 & 0.44 \\
2009 & 3.40 & -0.63 & 0.44 & -3.38 & 0.57 & 8.04 & 0.46 \\
2010 & 3.50 & -0.47 & 0.45 & -3.22 & 0.57 & 8.25 & 0.48 \\
2011 & 3.51 & -0.42 & 0.46 & -3.28 & 0.57 & 8.23 & 0.48 \\
2012 & 3.55 & -0.41 & 0.46 & -2.99 & 0.58 & 8.42 & 0.49 \\
\hline $2007-2012^{29}$ & 3.47 & -0.45 & 0.46 & -3.06 & 0.58 & 8.03 & 0.46
\end{tabular}

\begin{tabular}{l|llllll} 
& $\begin{array}{l}\text { Compensation } \\
\text { Coverage }\end{array}$ & $\begin{array}{l}\text { CC (Stand. } \\
\text { \& Trans.) }\end{array}$ & Time Period & $\begin{array}{l}\text { TP (Stand. \& } \\
\text { Trans.) }\end{array}$ & Fog-Index & $\begin{array}{l}\text { Number of } \\
\text { Words }\end{array}$ \\
\hline 2007 & 2.99 & 0.33 & 1.37 & 0.09 & 31.85 & 124.91 \\
2008 & 3.09 & 0.34 & 1.41 & 0.10 & 33.00 & 136.66 \\
2009 & 3.20 & 0.36 & 1.52 & 0.13 & 33.04 & 146.47 \\
2010 & 3.12 & 0.35 & 1.66 & 0.17 & 33.60 & 148.88 \\
2011 & 3.08 & 0.34 & 1.67 & 0.17 & 33.16 & 145.45 \\
2012 & 3.06 & 0.34 & 1.72 & 0.18 & 33.34 & 144.76 \\
\hline $2007-2012$ & 3.09 & 0.34 & 1.56 & 0.14 & 33.00 & 141.19
\end{tabular}

\footnotetext{
${ }^{29}$ Mean values differ slightly to those reported in Panel A of Table 3 due to rounding issues.
} 
Panel C: Index description

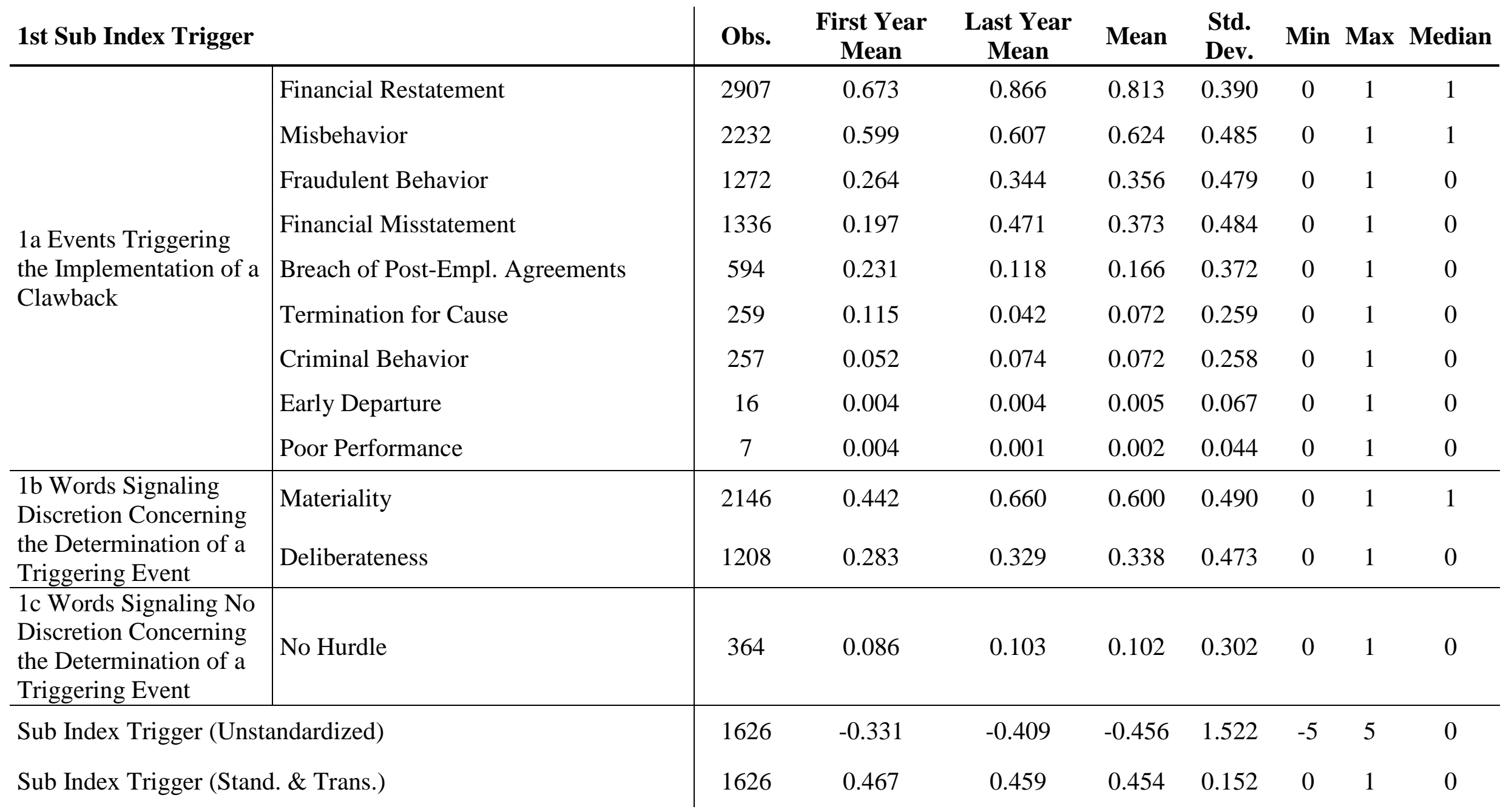




\begin{tabular}{|c|c|c|c|c|c|c|c|c|}
\hline 2nd Sub Index Enforcement & Obs. & $\begin{array}{c}\text { First Year } \\
\text { Mean }\end{array}$ & $\begin{array}{c}\text { Last Year } \\
\text { Mean }\end{array}$ & Mean & $\begin{array}{l}\text { Std. } \\
\text { Dev. }\end{array}$ & Min & Max & Median \\
\hline 2b Words Indicating that the Board Has the Right to Claw Back & 646 & 0.175 & 0.192 & 0.181 & 0.385 & 0 & 1 & 0 \\
\hline 2c Words Indicating that the Board Has Discretion to Claw Back & 1723 & 0.468 & 0.455 & 0.482 & 0.500 & 0 & 1 & 0 \\
\hline 2d Phrases Signaling Strong Clawback Actions & 1638 & 0.476 & 0.431 & 0.458 & 0.498 & 0 & 1 & 0 \\
\hline 2e Phrases Signaling Weak Clawback Actions & 2346 & 0.673 & 0.655 & 0.656 & 0.475 & 0 & 1 & 1 \\
\hline Sub Index Enforcement (Standardized and Transformed) & 2063 & 0.605 & 0.581 & 0.577 & 0.202 & 0 & 1 & 1 \\
\hline
\end{tabular}

\section{3rd Sub Index Compensation-Coverage}

\begin{tabular}{l|l}
\hline & $\begin{array}{l}\text { Incentive Compensation } \\
\text { Stocks and Stock Options } \\
\text { 3a Compensation Types } \\
\text { Covered }\end{array}$ \\
& $\begin{array}{l}\text { Cash Compensation } \\
\text { Indirect Profits: Stock Gains } \\
\text { Other Compensation }\end{array}$ \\
\hline 3b Compensation & $\begin{array}{l}\text { Stock Option Features } \\
\text { Features }\end{array}$ \\
\hline
\end{tabular}

Sub Index Compensation-Coverage (Unstandardized)

Sub Index Compensation-Coverage (Stand. \& Trans.)

\begin{tabular}{cccccccc} 
Obs. & $\begin{array}{c}\text { First Year } \\
\text { Mean }\end{array}$ & $\begin{array}{c}\text { Last Year } \\
\text { Mean }\end{array}$ & Mean & $\begin{array}{c}\text { Std. } \\
\text { Dev. }\end{array}$ & Min & Max & Median \\
\hline 3464 & 0.955 & 0.976 & 0.968 & 0.176 & 0 & 1 & 1 \\
1949 & 0.513 & 0.565 & 0.545 & 0.498 & 0 & 1 & 1 \\
1658 & 0.413 & 0.471 & 0.463 & 0.499 & 0 & 1 & 0 \\
739 & 0.219 & 0.181 & 0.207 & 0.405 & 0 & 1 & 0 \\
275 & 0.086 & 0.068 & 0.077 & 0.266 & 0 & 1 & 0 \\
1166 & 0.379 & 0.303 & 0.326 & 0.469 & 0 & 1 & 0 \\
905 & 0.175 & 0.260 & 0.253 & 0.435 & 0 & 1 & 0 \\
289 & 0.086 & 0.073 & 0.081 & 0.273 & 0 & 1 & 0 \\
\hline 1231 & 2.985 & 3.058 & 3.095 & 1.723 & 0 & 9 & 3 \\
1231 & 0.332 & 0.340 & 0.344 & 0.192 & 0 & 1 & 0
\end{tabular}




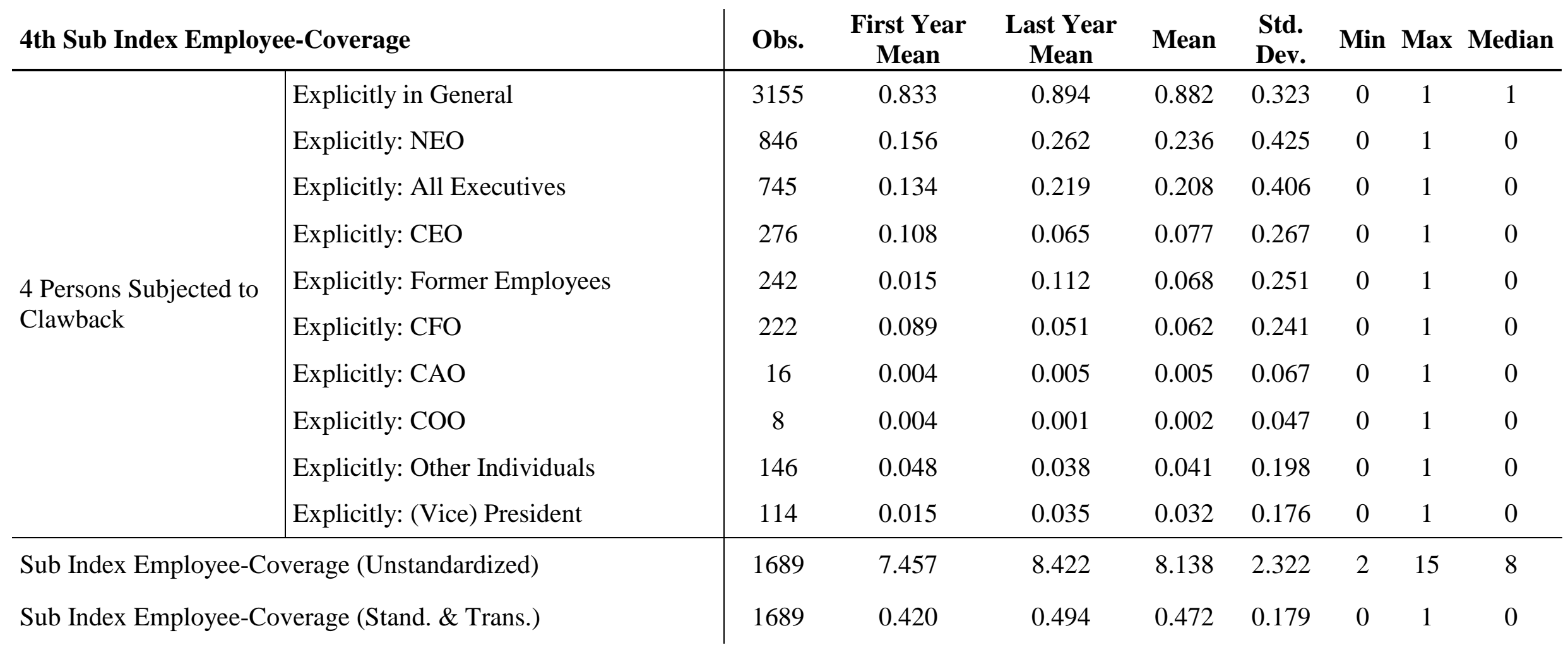

\begin{tabular}{|c|c|c|c|c|c|c|c|c|c|}
\hline \multicolumn{2}{|c|}{ 5th Sub Index Time Period } & \multirow{2}{*}{$\begin{array}{c}\text { Obs. } \\
42\end{array}$} & \multirow{2}{*}{$\begin{array}{c}\begin{array}{c}\text { First Year } \\
\text { Mean }\end{array} \\
0.019\end{array}$} & \multirow{2}{*}{$\begin{array}{c}\begin{array}{c}\text { Last Year } \\
\text { Mean }\end{array} \\
0.006\end{array}$} & \multirow{2}{*}{$\frac{\text { Mean }}{0.012}$} & \multirow{2}{*}{$\begin{array}{c}\begin{array}{c}\text { Std. } \\
\text { Dev. }\end{array} \\
0.108\end{array}$} & \multirow{2}{*}{$\frac{\text { Min }}{0}$} & \multirow{2}{*}{$\frac{\text { Max }}{1}$} & \multirow{2}{*}{$\frac{\text { Median }}{0}$} \\
\hline \multirow{4}{*}{5 Clawback Period } & Shorter/Equal 6 Months & & & & & & & & \\
\hline & Shorter/Equal 12 Months & 286 & 0.130 & 0.059 & 0.080 & 0.271 & 0 & 1 & 0 \\
\hline & Shorter/Equal 24 Months & 155 & 0.045 & 0.038 & 0.043 & 0.204 & 0 & 1 & 0 \\
\hline & Shorter/Equal 36 Months & 405 & 0.019 & 0.165 & 0.113 & 0.317 & 0 & 1 & 0 \\
\hline \multicolumn{2}{|c|}{ Sub Index Time Period (Unstandardized) } & 542 & 1.368 & 1.720 & 1.606 & 1.145 & 1 & 5 & 1 \\
\hline
\end{tabular}




\section{TABLE 4}

\section{Correlation matrices}

Panels A - E present Pearson-correlations of each component of and within each sub-index. Panel F presents Pearson-correlations of all sub indices. $* * *, * *, *$ denotes significance at the $1 \%, 5 \%$, and $10 \%$ level.

\section{Panel A: Correlation matrix for sub index Trigger}

\begin{tabular}{|c|c|c|c|c|c|c|c|c|c|c|c|c|c|c|}
\hline & & 1 & 2 & 3 & 4 & 5 & 6 & 7 & 8 & 9 & 10 & 11 & 12 & 13 \\
\hline 1 & Financial Restatement & 1 & & & & & & & & & & & & \\
\hline 2 & Misbehavior & $0.15^{* * *}$ & 1 & & & & & & & & & & & \\
\hline 3 & Fraudulent Behavior & $0.30 * * *$ & $0.30 * * *$ & 1 & & & & & & & & & & \\
\hline 4 & Financial Misstatement & $0.10^{* * *}$ & $0.08 * * *$ & $0.03 *$ & 1 & & & & & & & & & \\
\hline 5 & Breach of PE-Agreements & $-0.20 * * *$ & $0.08 * * *$ & $-0.08 * * *$ & $-0.07 * * *$ & 1 & & & & & & & & \\
\hline 6 & Termination for Cause & $-0.10^{* * *}$ & $0.10^{* * *}$ & $-0.05 * * *$ & 0.006 & $0.10^{* * *}$ & 1 & & & & & & & \\
\hline 7 & Criminal Behavior & $-0.07 * * *$ & $0.20 * * *$ & $0.20 * * *$ & -0.02 & $0.10 * * *$ & $0.10 * * *$ & 1 & & & & & & \\
\hline 8 & Early Departure & $-0.05 * * *$ & -0.02 & $-0.04 * * *$ & $-0.03^{*}$ & 0.01 & $0.10^{* * *}$ & -0.02 & 1 & & & & & \\
\hline 9 & Poor Performance & $-0.04 * * *$ & $-0.04^{* *}$ & $-0.03^{*}$ & -0.001 & -0.02 & -0.01 & -0.01 & -0.003 & 1 & & & & \\
\hline 10 & No Restatement & $0.04^{* *}$ & -0.007 & 0.02 & $0.05 * * *$ & -0.01 & $0.07 * * *$ & -0.008 & -0.002 & -0.001 & 1 & & & \\
\hline 11 & Materiality & $0.22^{* * *}$ & $0.50 * * *$ & $0.20 * * *$ & $0.30 * * *$ & $0.07 * * *$ & $0.10^{* * *}$ & $0.2^{* * *}$ & -0.02 & -0.02 & 0.008 & 1 & & \\
\hline 12 & Deliberateness & $0.10^{* * *}$ & $0.40^{* * *}$ & $0.50 * * *$ & $0.10^{* * *}$ & $-0.08 * * *$ & $0.03 *$ & $0.2 * * *$ & $-0.04 * *$ & -0.03 & -0.02 & $0.30 * * *$ & 1 & \\
\hline 13 & No Hurdle & $0.10^{* * *}$ & $0.10 * * *$ & $0.10 * * *$ & $0.10 * * *$ & 0.01 & $0.03^{* *}$ & 0.01 & -0.01 & -0.01 & $0.08^{* * *}$ & $0.08^{* * *}$ & $0.1^{* * *}$ & 1 \\
\hline
\end{tabular}


Panel B: Correlation matrix for sub index Enforcement

\begin{tabular}{ll|cccc} 
& $\mathbf{1}$ & $\mathbf{2}$ & $\mathbf{3}$ & $\mathbf{4}$ & $\mathbf{5}$ \\
\hline $\mathbf{1}$ & Words Indicating that the Board Is Obligated to Claw Back & 1 & & & \\
$\mathbf{2}$ & Words Indicating that the Board Has the Right to Claw Back & $-0.15^{* * *}$ & 1 & & \\
$\mathbf{3}$ & Words Indicating that the Board Has Discretion to Claw Back & $0.12^{* * *}$ & $-0.12^{* * *}$ & 1 & \\
$\mathbf{4}$ & Phrases Signaling Strong Clawback Actions & $0.20^{* * *}$ & $-0.05^{* * *}$ & $0.30^{* * *}$ & 1 \\
$\mathbf{5}$ & Phrases Signaling Weak Clawback Actions & $0.19^{* * *}$ & $-0.08^{* * *}$ & $0.42^{* * *}$ & $0.43^{* * *}$ \\
\hline
\end{tabular}

Panel C: Correlation matrix for sub index Compensation-Coverage

\begin{tabular}{|c|c|c|c|c|c|c|c|c|c|}
\hline & & 1 & 2 & 3 & 4 & 5 & 6 & 7 & 8 \\
\hline 1 & Incentive Compensation & 1 & & & & & & & \\
\hline 2 & Stocks and Stock Options & $0.32 * * *$ & 1 & & & & & & \\
\hline 3 & Cash Compensation & $0.15^{* * *}$ & $0.19 * * *$ & 1 & & & & & \\
\hline 4 & Indirect Profits: Stock Gains & $0.12 * * *$ & $0.49 * * *$ & $0.05^{* * *}$ & 1 & & & & \\
\hline 5 & Other Compensation & $0.08 * * *$ & $0.11^{* * *}$ & $0.04 * *$ & $0.12 * * *$ & 1 & & & \\
\hline 6 & Stock Option Features & $0.29 * * *$ & $0.70^{* * *}$ & $0.08^{* * *}$ & $0.36^{* * *}$ & $0.11^{* * *}$ & 1 & & \\
\hline 7 & Time Horizon & $0.23 * * *$ & $0.03 *$ & $0.06^{* * *}$ & 0.02 & $0.06^{* * *}$ & $0.12 * * *$ & 1 & \\
\hline 8 & Other Compensation Features & $0.16^{* * *}$ & $0.34^{* * *}$ & $0.04 * *$ & $0.20 * * *$ & $0.03 *$ & $0.36^{* * *}$ & 0.01 & 1 \\
\hline
\end{tabular}


Panel D: Correlation matrix for sub index Employee-Coverage

\begin{tabular}{|c|c|c|c|c|c|c|c|c|c|c|c|}
\hline & & 1 & 2 & 3 & 4 & 5 & 6 & 7 & 8 & 9 & 10 \\
\hline 1 & Executives in General & 1 & & & & & & & & & \\
\hline 2 & Explicitly: NEO & -0.002 & 1 & & & & & & & & \\
\hline 3 & Explicitly: All Executives & $0.30 * * *$ & $-0.07 * * *$ & 1 & & & & & & & \\
\hline 4 & Explicitly: CEO & 0.01 & $-0.03 *$ & $0.08^{* * *}$ & 1 & & & & & & \\
\hline 5 & Explicitly: Former Empl. & $0.20 * * *$ & $0.08 * * *$ & -0.02 & -0.01 & 1 & & & & & \\
\hline 6 & Explicitly: CFO & -0.02 & $-0.03 *$ & $0.06 * * *$ & $0.8^{* * *}$ & -0.03 & 1 & & & & \\
\hline 7 & Explicitly: CAO & $0.04^{* * *}$ & -0.03 & $0.06^{* * *}$ & 0.01 & -0.006 & $0.07 * * *$ & 1 & & & \\
\hline 8 & Explicitly: COO & $0.04^{* * *}$ & 0.02 & -0.02 & $0.08 * * *$ & $0.10 * * *$ & 0.02 & -0.003 & 1 & & \\
\hline 9 & Explicitly: Other Individuals & $0.20 * * *$ & -0.02 & $0.04 * *$ & $0.20 * * *$ & 0.01 & $0.20 * * *$ & -0.009 & $0.05 * * *$ & 1 & \\
\hline 10 & Explicitly: (Vice) President & $0.09 * * *$ & 0.006 & 0.01 & $0.20 * * *$ & $0.05^{* * *}$ & $0.09 * * *$ & $0.04^{* *}$ & $0.08^{* * *}$ & $0.07 * * *$ & 1 \\
\hline
\end{tabular}

\section{Panel E: Correlation matrix for sub index Time Period}

\begin{tabular}{|c|c|c|c|c|c|c|c|}
\hline & & 1 & 2 & 3 & 4 & 5 & 6 \\
\hline 1 & Shorter/Equal 6 Months & 1 & & & & & \\
\hline 2 & Shorter/Equal 12 Months & $-0.03 *$ & 1 & & & & \\
\hline 3 & Shorter/Equal 24 Months & -0.02 & $-0.06 * * *$ & 1 & & & \\
\hline 4 & Shorter/Equal 36 Months & $-0.04 * *$ & $-0.1 * * *$ & $-0.08 * * *$ & 1 & & \\
\hline 5 & Longer Than 36 Months & -0.02 & $-0.05 * * *$ & $-0.03 * *$ & $-0.06 * * *$ & 1 & \\
\hline 6 & Starting After Termination/Specified Date & -0.01 & -0.02 & $0.04 * *$ & 0.01 & -0.01 & 1 \\
\hline
\end{tabular}


Panel F: Correlation matrix for all sub indices

2 Sub Index Enforcement (Unstandardized)

3 Sub Index Employee-Coverage (Unstandardized)

4 Sub Index Compensation-Coverage (Unstandardized)

5 Sub Index Time-Period (Unstandardized)

2

3

4

1

$0.063 * * * \quad 1$

$-0.10 * * * \quad-0.026 \quad 1$

$\begin{array}{llll}-0.018 & -0.138 * * * & 0.142 * * * & 1\end{array}$

$\begin{array}{lllll}0.098^{* * *} & 0.025 & 0.141 * * * & 0.134^{* * *} & 1\end{array}$ 
TABLE 5

Summary statistics

Panel A presents descriptive statistics of the dependent and independent variables. Panel B presents the t-test testing whether the means of the independent variables of clawback firms belonging to the $10 \%$ percentile equal the means of clawback firms belonging to the $90 \%$ percentile of the Deterrent-index. Please see Appendix I for the definition of variables.

Panel A: Descriptive statistics

\begin{tabular}{l|cccccc} 
& Observations & Mean & Std. Dev. & Min & Median & Max \\
\hline Deterrent-index & 2118 & 3.47 & 0.74 & 1.65 & 3.46 & 5.56 \\
Peer Litigation & 5929 & 0.02 & 0.03 & 0.00 & 0.02 & 0.47 \\
CEO tenure & 5929 & 7.61 & 0.91 & 2.71 & 7.69 & 10.03 \\
Executives' Pay Slice & 5929 & 0.14 & 1.97 & 0.00 & 0.04 & 125.45 \\
CEO Pay Slice & 5929 & 0.46 & 0.06 & 0.10 & 0.46 & 0.92 \\
Board Size & 5929 & 16.28 & 5.22 & 5.00 & 16.00 & 41.00 \\
Sales Growth & 5929 & 0.08 & 0.15 & -0.61 & 0.06 & 5.29 \\
Busy Directors & 5929 & 0.02 & 0.04 & 0.00 & 0.00 & 0.41 \\
CEO Chair & 5929 & 0.55 & 0.50 & 0.00 & 1.00 & 1.00 \\
Audit Committee Size & 5929 & 5.62 & 2.36 & 2.00 & 5.00 & 18.00 \\
Leverage & 5929 & 0.21 & 0.20 & 0.00 & 0.17 & 0.99 \\
Profitability & 5929 & 0.15 & 0.08 & -0.19 & 0.14 & 1.25 \\
Tobin's Q & 5929 & 1.66 & 1.02 & 0.03 & 1.35 & 12.07 \\
Share Return & 5929 & 0.10 & 0.56 & -0.85 & 0.04 & 5.27 \\
Management & 5929 & 0.09 & 0.15 & 0.00 & 0.04 & 1.00 \\
Ownership & 5929 & 1.24 & 1.67 & 0.00 & 0.00 & 4.24 \\
Fog Index & 5929 & 0.03 & 0.05 & 0.00 & 0.00 & 0.60 \\
Firm Complexity & 7.79 & 1.51 & 4.02 & 7.65 & 12.72 \\
Firm Size & 5929 & & & &
\end{tabular}


Panel B: T-tests of differences in means of all independent variables for firms belonging to the $10 \%$ and $90 \%$ percentile of the Deterrent-index

\begin{tabular}{|c|c|c|c|}
\hline Variable & $\begin{array}{c}\text { smaller than } \\
\text { deterrent- } \\
\text { index p10 } \\
\text { mean } \\
\end{array}$ & $\begin{array}{c}\text { larger than } \\
\text { deterrent- } \\
\text { index p90 } \\
\text { mean } \\
\end{array}$ & $\begin{array}{l}\text { p-value for test in } \\
\text { mean differences } \\
\text { (p10) }\end{array}$ \\
\hline Audit Committee Size & 6.399 & 6.337 & 0.739 \\
\hline Board Size & 18.777 & 17.103 & 0.000 \\
\hline Busy Directors & 0.017 & 0.023 & 0.066 \\
\hline CEO Chair & 0.545 & 0.509 & 0.349 \\
\hline CEO Pay Slice & 0.462 & 0.458 & 0.472 \\
\hline CEO Tenure & 7.555 & 7.354 & 0.008 \\
\hline Executives' Pay Slice & 0.320 & 0.061 & 0.331 \\
\hline Firm Complexity & 0.024 & 0.027 & 0.404 \\
\hline Fog Index & 3.459 & 3.502 & 0.159 \\
\hline Leverage & 0.262 & 0.253 & 0.580 \\
\hline Management Ownership & 0.062 & 0.097 & 0.001 \\
\hline Peer Litigation & 0.027 & 0.026 & 0.854 \\
\hline Profitability & 0.117 & 0.129 & 0.121 \\
\hline Sales Growth & 0.067 & 0.037 & 0.007 \\
\hline Share Return & 0.110 & 0.144 & 0.499 \\
\hline Firm Size & 8.442 & 7.965 & 0.000 \\
\hline Tobin’s Q & 1.446 & 1.566 & 0.055 \\
\hline
\end{tabular}


TABLE 6

\section{Regression results}

Table 6 presents results of our multivariate analyses. Columns (1) and (2) display first and second stage Probit and OLS regressions (Heckman two-stage model). Column (3) presents results of a Tobit regression whereas we set the deterrent index for non-adopters equal to zero. All models control for industry effects (2-digit sic codes) and time trends. Standard errors are clustered at the firm level. Values in parentheses show t-statistics. ***, **, * denote significance at the $10 \%, 5 \%$, and $1 \%$ level. Please see Appendix I for the definition of variables.

\begin{tabular}{|c|c|c|c|}
\hline Dependent Variable & $\begin{array}{c}(1) \\
\text { 1st Stage } \\
\text { Clawback } \\
\end{array}$ & $\begin{array}{c}\text { (2) } \\
\text { 2nd Stage } \\
\text { Deterrent Index }\end{array}$ & $\begin{array}{c}\text { (3) } \\
\text { Tobit } \\
\text { Deterrent Index }\end{array}$ \\
\hline Peer Adoption & $\begin{array}{c}3.345^{* * * *} \\
(8.78)\end{array}$ & & \\
\hline Inverse Mills' Ratio & & $\begin{array}{c}-0.183 * * \\
(0.087)\end{array}$ & \\
\hline Peer Litigation & $\begin{array}{l}0.508 \\
(0.68)\end{array}$ & $\begin{array}{l}0.439 \\
(0.84)\end{array}$ & $\begin{array}{l}0.495 \\
(0.96)\end{array}$ \\
\hline CEO Tenure & $\begin{array}{c}-0.085 * * \\
(-2.45)\end{array}$ & $\begin{array}{l}-0.024 \\
(-0.87)\end{array}$ & $\begin{array}{l}-0.033 \\
(-1.24)\end{array}$ \\
\hline Executives' Pay Slice & $\begin{array}{l}-0.000 \\
(-0.00)\end{array}$ & $\begin{array}{c}-0.011^{*} \\
(-1.80)\end{array}$ & $\begin{array}{c}-0.011^{* *} \\
(-1.99)\end{array}$ \\
\hline CEO Pay Slice & $\begin{array}{l}0.163 \\
(0.34)\end{array}$ & $\begin{array}{l}-0.380 \\
(-0.92)\end{array}$ & $\begin{array}{l}-0.343 \\
(-0.83)\end{array}$ \\
\hline Board Size & $\begin{array}{c}0.035^{* * * *} \\
(3.82)\end{array}$ & $\begin{array}{c}-0.019 * * * \\
(-2.62)\end{array}$ & $\begin{array}{c}-0.015 * * \\
(-2.15)\end{array}$ \\
\hline Sales Growth & $\begin{array}{c}-1.097 * * * \\
(-4.83)\end{array}$ & $\begin{array}{l}-0.284 \\
(-1.29)\end{array}$ & $\begin{array}{c}-0.411^{* *} \\
(-1.96)\end{array}$ \\
\hline Busy Directors & $\begin{array}{l}0.488 \\
(0.70)\end{array}$ & $\begin{array}{c}1.331^{* * * *} \\
(2.63)\end{array}$ & $\begin{array}{c}1.394 * * * \\
(2.79)\end{array}$ \\
\hline CEO Chair & $\begin{array}{l}0.088 \\
(1.27)\end{array}$ & $\begin{array}{l}-0.045 \\
(-0.82)\end{array}$ & $\begin{array}{l}-0.036 \\
(-0.67)\end{array}$ \\
\hline Audit Committee Size & $\begin{array}{l}0.005 \\
(0.27)\end{array}$ & $\begin{array}{l}0.005 \\
(0.34)\end{array}$ & $\begin{array}{l}0.004 \\
(0.30)\end{array}$ \\
\hline Leverage & $\begin{array}{c}-0.560^{* * *} \\
(-2.66)\end{array}$ & $\begin{array}{l}0.093 \\
(0.47)\end{array}$ & $\begin{array}{l}0.046 \\
(0.24)\end{array}$ \\
\hline Profitability & $\begin{array}{l}0.742^{*} \\
(1.83)\end{array}$ & $\begin{array}{l}0.596^{*} \\
(1.74)\end{array}$ & $\begin{array}{c}0.693 * * \\
(2.02)\end{array}$ \\
\hline Tobin's Q & $\begin{array}{l}-0.063 \\
(-1.62)\end{array}$ & $\begin{array}{l}-0.046 \\
(-1.15)\end{array}$ & $\begin{array}{l}-0.054 \\
(-1.38)\end{array}$ \\
\hline Share Return & $\begin{array}{l}-0.056 \\
(-1.51)\end{array}$ & $\begin{array}{l}-0.020 \\
(-0.66)\end{array}$ & $\begin{array}{l}-0.027 \\
(-0.88)\end{array}$ \\
\hline $\begin{array}{l}\text { Management } \\
\text { Ownership }\end{array}$ & $-0.849 * * *$ & $0.530 * *$ & $0.422^{* *}$ \\
\hline Fog Index & $(-3.26)$ & $\begin{array}{c}(2.51) \\
0.132^{* * *} \\
(3.44)\end{array}$ & $\begin{array}{c}(2.07) \\
0.131^{* * *} \\
(3.41)\end{array}$ \\
\hline
\end{tabular}




\begin{tabular}{l|ccc} 
Firm Complexity & 0.101 & 0.548 & 0.564 \\
& $(0.12)$ & $(0.71)$ & $(0.73)$ \\
Firm Size & $0.266^{* * *}$ & -0.033 & -0.006 \\
& $(8.81)$ & $(-1.26)$ & $(-0.26)$ \\
Constant & $-4.461^{* * *}$ & $3.772^{* * *}$ & $3.415^{* * *}$ \\
& $(-9.58)$ & $(9.89)$ & $(10.15)$ \\
\hline \multirow{2}{*}{ Observations } & 5,929 & 2,118 & 5,929
\end{tabular}

